\title{
Conjugation of $N$-acylhydrazone and 1,2,4-oxadiazole leads to the identification of active antimalarial agents
}

\author{
José Maurício dos Santos Filho ${ }^{\mathrm{a}, *}$, Diogo Manoel Alves de Queiroz e Silva ${ }^{\mathrm{a}}$, Taís Soares Macedo ${ }^{\mathrm{b}}$, \\ Helena Mariana Pitangueira Teixeira ${ }^{\mathrm{b}}$, Diogo Rodrigo Magalhaes Moreira ${ }^{\mathrm{b}}$, Soura Challal ${ }^{\mathrm{c}}$, \\ Jean-Luc Wolfender ${ }^{c}$, Emerson Ferreira Queiroz ${ }^{c}$, Milena Botelho Pereira Soares ${ }^{\mathrm{b}, \mathrm{d}}$ \\ ${ }^{a}$ Laboratory of Design and Synthesis Applied to Medicinal Chemistry-SintMed ${ }^{\circledR}$, Centro de Tecnologia e Geociências, Universidade Federal de Pernambuco, CEP 50740-521 Recife, \\ PE, Brazil \\ ${ }^{\mathrm{b}}$ Centro de Pesquisas Gonçalo Moniz, Fundação Oswaldo Cruz, CEP 40296-710 Salvador, BA, Brazil

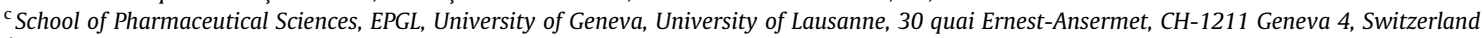 \\ ${ }^{\mathrm{d}}$ Centro de Biotecnologia e Terapia Celular, Hospital São Rafael, CEP 41253-190 Salvador, BA, Brazil
}

\section{A R T I C L E I N F O}

\section{Article history:}

Received 20 July 2016

Revised 4 September 2016

Accepted 7 September 2016

Available online $\mathrm{xxxx}$

\section{Keywords:}

Malaria

Plasmodium falciparum

Drug design

$N$-Acylhydrazones

1,2,4-Oxadiazoles

\begin{abstract}
A B S T R A C T
Malaria, caused by several Plasmodium species, is the major life-threatening parasitic infection worldwide. Due to the parasite resistance to quinoline based drugs, the search for antimalarial agents is necessary. Here, we report the structural design, synthesis and antiparasitic evaluation of two novel series of $1,2,4$-oxadiazoles in conjugation to $\mathrm{N}$-acylhydrazones, both groups recognized as privileged structures, as well as the studies on the antimalarial activity of 16 previous described analogues. By varying substituents attached to the phenyl ring, it was possible to retain, enhance or increase the antiparasitic activity in comparison to the nonsubstituted derivatives. Replacement of substituted aryl rings by ferrocenyl and cinnamyl moieties attached in the $\mathrm{N}$-acylhydrazone ablated the antiparasitic response, evidencing the structural features associated with the activity. Active compounds exhibited in vitro potency similar to mefloquine, but not all inhibited $\beta$-hematin formation. Additionally, the active compounds displayed low cytotoxicity in HepG2 cells and did not cause hemolysis in uninfected erythrocytes. In Plasmodium berghei-infected mice, the compounds reduced parasitemia but exhibited limited efficacy in increasing mice survival when compared to chloroquine, suggesting that pharmacological improvement is still necessary.
\end{abstract}

(c) 2016 Elsevier Ltd. All rights reserved.

\section{Introduction}

Malaria represents a major threat to the public human health worldwide, with over 230 million clinical cases and about 660,000 deaths annually. In comparison to the last decade, the mortality is decreasing, however, malaria remains widespread in endemic areas. ${ }^{1}$ Current treatment relies on quinolines and artemisinin combinations; even so, there are significant problems of drug resistance. ${ }^{2,3}$ It is thus important to identify drug candidates based on new chemotypes. To address this need, phenotype-based antimalarial screening has been employed to identify active compounds chemically distinct from artemisinin and quinolines. For instance, this approach has led to the discovery of the ozonide compounds arterolane and OZ439, the spiroindolone KAE609, the

\footnotetext{
* Corresponding author. Tel.: +55 81 21267288; fax: +55 8121267278 .

E-mail address: mauricio_santosfilho@yahoo.com.br (J.M. dos Santos Filho).
}

naphthoquinone decoquinate as well as the thiazole albitiazolium. ${ }^{4-8}$ These compounds are considered to be drug candidates and are likely to enter into clinical trials, strengthening the concept that phenotype-based screening is a suitable approach for antimalarial drug discovery.

Oxadiazoles are a class of heterocyclic compounds useful for the development of anti-infectious agents. ${ }^{9-12}$ The most notable example is the class of the 1,2,5-oxadiazole-2-oxides, collectively known as furoxans, which have a broad spectrum of antiparasitic activity, including antimalarial property (Fig. 1). Furoxans exert antiparasitic activity in part by releasing endogenous nitric oxide, which is an antimicrobial molecule. Interestingly, furoxan derivatives without the $\mathrm{N}$-oxide group, which is essential to confer a nitric oxide release, also exhibit antiparasitic properties. This suggests that furoxan has a multi-target mechanism of action, therefore oxadiazoles are considered potential antiparasitic compounds. ${ }^{12,13}$ 


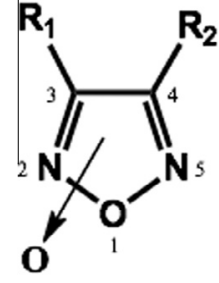

(1)

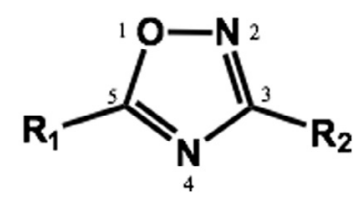

(2)
Figure 1. General representation of 1,2,5-oxadiazole-2-oxide (1) and 1,2,4oxadiazoles (2).

Previously, $N$-acylhydrazones derived from 3-aryl-1,2,4-oxadiazoles were identified as antiparasitic agents against Trypanosoma cruzi, displaying low toxicity in both in vitro and in vivo experiments as well as high efficacy in in vivo models of T. cruzi-infection. ${ }^{14,15}$ In this line, $N$-acylhydrazones derived from 7-chloroquinoline and 1,3-diiminoisoindoline exhibited strong antimalarial activities. ${ }^{16,17}$ Based on these findings, here we investigated the antimalarial activity for $\mathrm{N}$-acylhydrazones derived from 3-aryl-1,2,4-oxadiazoles (Fig. 2). First, a series of known $\mathrm{N}$-acylhydrazones bearing a 4-hydroxy-3-methoxyphenyl (vanillinyl) portion SintMed (1-8), planned and synthesized on the basis of molecular hybridization concepts, was investigated. Since the $\mathrm{N}$-acylhydrazone-1,2,4-oxadiazole moiety has been identified as important to disclose antiparasitic activity, ${ }^{14,15}$ its structural association with the vanillinyl portion was exploited as a promising strategy to increase the molecular recognition by the biological system. Vanillin itself and its derivatives are largely described as biological active compounds, ${ }^{18}$ reinforcing the grounds of this strategy. The second series, also previously described in our group, has arisen from the exploitation of the isosteric relation between the vanillinyl group and the 1,3-benzodioxole-5-phenyl (piperonyl) moiety SintMed (9-16), also a portion of natural occurrence.

In addition, sixteen new $\mathrm{N}$-acylhydrazone-1,2,4-oxadiazoles were prepared for the first time and evaluated for their antimalarial activities. Following the defined strategy, the first unexampled series incorporates a cinnamyl moiety attached to the $\mathrm{N}$-acylhydrazone, which yielded the compounds SintMed (17-24). This molecular modification was investigated due to the important role played by the cinnamyl group present in molecules with demonstrated antimalarial activity. ${ }^{19 a, b}$ Another novel series of $\mathrm{N}$-acylhydrazone-1,2,4-oxadiazoles includes a ferrocenyl substitution, a non-natural occurring and unique group, leading to

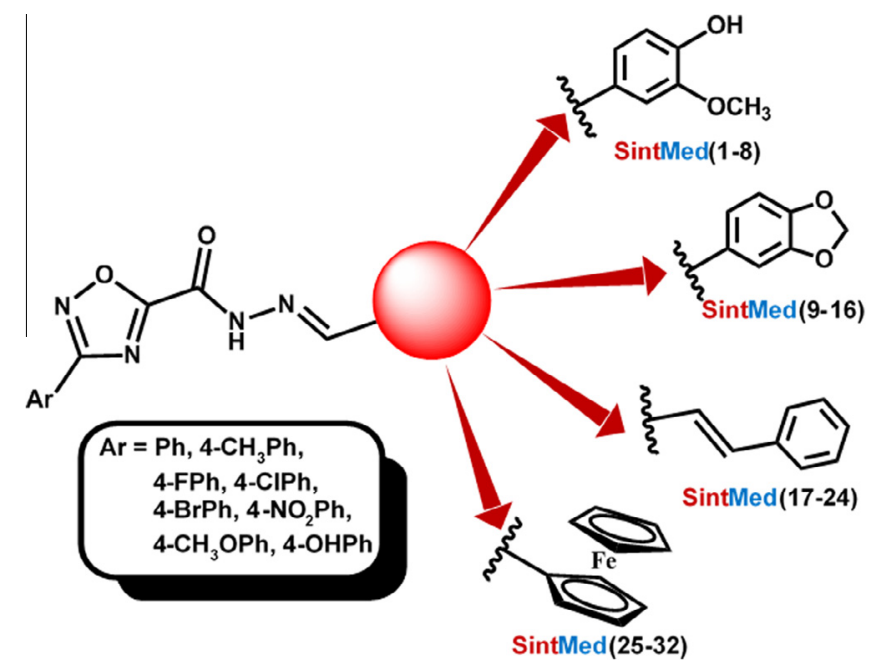

Figure 2. Structure of the $N$-acylhydrazone-1,2,4-oxadiazoles analogues SintMed (1-32) evaluated as antimalarial compounds.
SintMed (25-32). Ferrocenyl has been for long time associated to bioactive molecules, promoting meaningful biological improvements, as demonstrated for ferroquine, a ferrocenyl analogue of chloroquine, which was not only active against chloroquine sensitive Plasmodium parasites, but also against resistant strains. ${ }^{20 a, b}$ Therefore, association of the $N$-acylhydrazone-1,2,4-oxadiazole structure with each of the selected groups can represent a great possibility to disclose new potent active antimalarials agents, whose remarkable property is the structural simplicity and low cost of production.

In vitro screening of compounds SintMed (1-32) led us to identify some of them having a potent activity and selectivity against the blood-stage Plasmodium falciparum, as well as to acquire a better understanding of structure-activity relationships implied in the modification of the $N$-acylhydrazone-1,2,4-oxadiazole basic structure used in our group as a fundamental model in drug design.

\section{Results and discussion}

\subsection{Chemistry}

The synthesis of compounds SintMed (17-32), depicted in Scheme 1 , is based on a method developed by our group. ${ }^{15}$ Briefly, commercially available aryl nitriles were converted into 4-substituted arylamidoximes by refluxing during $4 \mathrm{~h}$ in the presence of hydroxylamine with good yields, which constitutes our primary start material. Under inert atmosphere and dry conditions, arylamidoximes react with monomethyl oxalyl chloride, leading to methyl 3-(4-arylsubstituted)-1,2,4-oxadiazole carboxylates, which were converted into the corresponding 1,2,4-oxadiazole hydrazides under mild condition.

Although the condensation of hydrazides with vanillin and piperonal, respectively, under sulfuric acid catalysis at room temperature leads easily to the series SintMed (1-8) and SintMed (9-16) as previously reported, this same condition did not work for synthesizing ferrocenyl derivatives SintMed (25-32). In order to overcome this inconvenience, the reaction between the hydrazides and ferrocenecarboxyaldehyde was carried out in the presence of cerium(III) chloride heptahydrate $\left(\mathrm{CeCl}_{3} \cdot 7 \mathrm{H}_{2} \mathrm{O}\right)$ as a catalyst with isolated average yields of $90 \%$, following a method recently developed in our laboratory. ${ }^{21}$

Compounds SintMed (25-32) were analyzed by usual ${ }^{1} \mathrm{H}$ NMR, and ${ }^{13} \mathrm{C}$ NMR. Signal assignments for the ferrocene group was assisted by DEPT, HSQC and HMBC experiments, in addition to comparing the findings with related literature. ${ }^{22,23}{ }^{1} \mathrm{H}$ NMR analysis of crude ferrocenyl compounds SintMed (25-32) revealed that only the E-isomer was formed, in agreement with previously reported outcomes for other compounds synthesized using this method. ${ }^{21}$ Due to the mild condition and low reaction time, cerium(III) chloride catalysis has proved to be highly stereoselective, leading exclusively to the thermodynamically more stable E-isomer. Considering that isomeric purity is important for pharmacological evaluation, the new series of cinnamyl derivatives SintMed (17-24) as well as compounds SintMed (1-16) were also synthesized in the presence of $\mathrm{CeCl}_{3}$-catalyst and yielded $E$-isomer only. Taking the ${ }^{1} \mathrm{H}$ NMR spectra of representative compounds SintMed23 and SintMed31, the stereoselectivity of the $\mathrm{CeCl}_{3}$-method can be easily corroborated (Fig. 3).

This outcome was analyzed by observing the signal of the iminic proton $(-\mathrm{N}=\mathrm{CH}-$ ), which ressonates at $\delta \approx 8.50-8.30 \mathrm{ppm}$. In previous reports, it was determined that this value is characteristic for $E$-isomers, while $Z$-isomers usually show signals at $\delta \approx 7.90$ $8.00 \mathrm{ppm}^{15,21}$ The presence of $E / Z$-isomers can also be established by observing the signal of the amide group (-CONH-), which splits up in two singlets when both isomers are formed. In all cases discussed in this work, only one signal for each of these groups was 


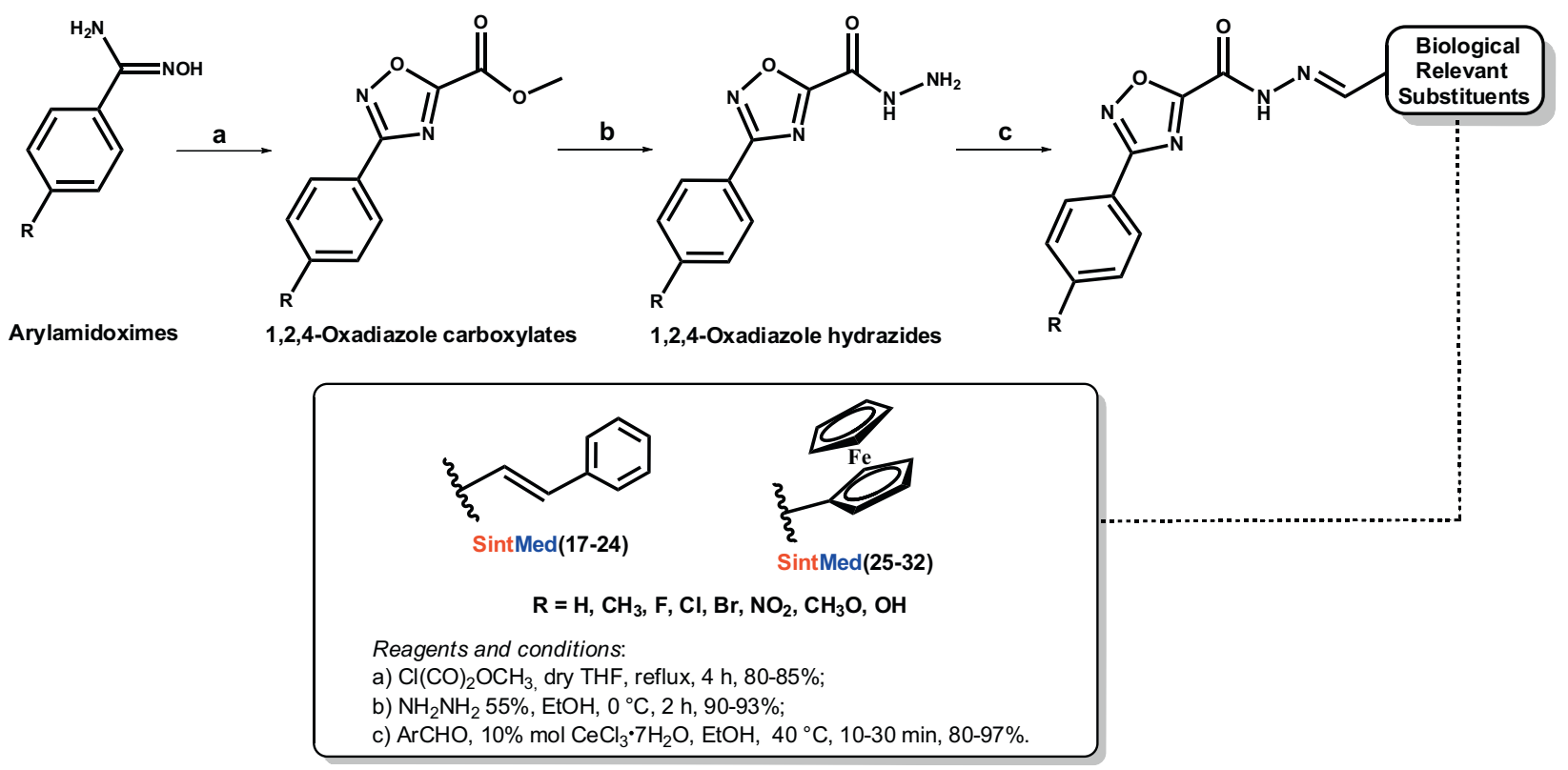

Scheme 1. Synthetic route for $N$-acylhydrazone-1,2,4-oxadiazole compounds.
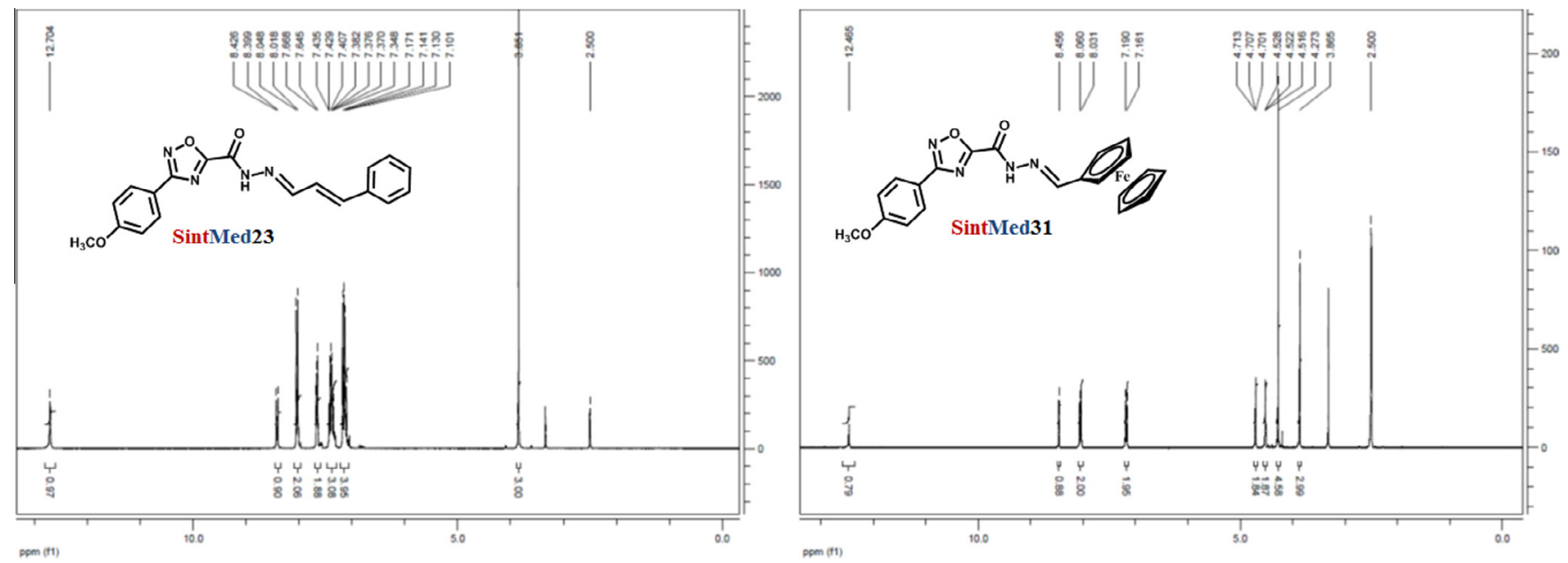

Figure 3. ${ }^{1} \mathrm{H}$ NMR spectra of compounds SintMed23 and SintMed31 as pure E-isomers.

observed, including the known compounds SintMed (1-16), which were previously described with signals of Z-isomers. ${ }^{15}$

\subsection{Pharmacological evaluation}

Compounds SintMed (1-32) were initially screened at $10 \mu \mathrm{g} / \mathrm{mL}$ against the chloroquine-resistant W2 strain of bloodstage $P$. falciparum (Table 1 ). Compounds which have inhibited more than $60 \%$ parasite growth at this concentration were considered active and had their $\mathrm{IC}_{50}$ values determined. Mefloquine (Mfq) was used as the reference antimalarial drug in these assays.

First, the parasite grown inhibited by compounds containing a 4-hydroxy-3-methoxyphenyl moiety SintMed (1-8) was investigated. The unsubstituted compound at phenyl ring SintMed1 was inactive, while the attachment of a methyl at position 4 of phenyl SintMed2 produced an active antimalarial compound. In contrast, attaching fluoro SintMed3, chlorine SintMed4 or methoxy SintMed7 substituents did not produce active compounds. But attaching a bromo SintMed5 or a nitro group SintMed6 increased the activity of both compounds. In comparison to the unsubstituted compound SintMed1, the attachment of a hydroxyl group SintMed8 disclosed a compound on the edge of the activity parameter. The series bearing the 1,3-benzodioxole moiety SintMed (9-16) was investigated, based on its close isosteric relation with the previous series SintMed (1-8). Except for the compound SintMed16, substituted with a hydroxy group, and possessing expressive activity, all other members of this series were inactive. Instead of a withdraw, this outcome gives some key clues about the nature of the structural requirements necessary to enhance the antimalarial activity of analogue molecules. The presence of a hydroxyl group linked to a phenyl ring at the $\mathrm{N}$-acylhydrazone-1,2,4-oxadiazole skeleton seems to be essential to the emergence of active antimalarial compounds.

This assumption has found support in the results for the series containing cinnamyl SintMed (17-24) and ferrocenyl SintMed (25-32) moieties, both inactive against $P$. falciparum. These preliminary observations narrow the structural possibilities that can be pursued in the search for new antimalarials based on the $\mathrm{N}$-acylhydrazone-1,2,4-oxadiazole chemotype. 
Table 1

Initial anti-P. falciparum screening against chloroquine-resistant W2 strain

\begin{tabular}{|c|c|c|c|c|c|}
\hline Compound & $\mathrm{R}$ & $\%$ inhibition $^{\mathrm{a}}$ & Compound & $\mathrm{R}$ & $\%$ inhibition $^{a}$ \\
\hline SintMed1 & $\mathrm{H}$ & 55.4 & SintMed5 & $\mathrm{Br}$ & 71.1 \\
\hline SintMed2 & $\mathrm{CH}_{3}$ & 61.1 & SintMed6 & $\mathrm{NO}_{2}$ & 68.7 \\
\hline SintMed3 & $\mathrm{F}$ & 24.7 & SintMed7 & $\mathrm{OCH}_{3}$ & 42.2 \\
\hline SintMed4 & $\mathrm{Cl}$ & 37.0 & SintMed8 & $\mathrm{OH}$ & 58.8 \\
\hline SintMed9 & $\mathrm{H}$ & 27.5 & SintMed13 & $\mathrm{Br}$ & 45.3 \\
\hline SintMed10 & $\mathrm{CH}_{3}$ & 21.9 & SintMed14 & $\mathrm{NO}_{2}$ & 33.9 \\
\hline SintMed11 & $\mathrm{F}$ & 31.6 & SintMed15 & $\mathrm{OCH}_{3}$ & 27.5 \\
\hline SintMed12 & $\mathrm{Cl}$ & 53.0 & SintMed16 & $\mathrm{OH}$ & 71.9 \\
\hline SintMed17 & $\mathrm{H}$ & 51.0 & SintMed21 & $\mathrm{Br}$ & 58.8 \\
\hline SintMed18 & $\mathrm{CH}_{3}$ & 52.7 & SintMed22 & $\mathrm{NO}_{2}$ & 25.7 \\
\hline SintMed19 & $\mathrm{F}$ & 34.3 & SintMed23 & $\mathrm{OCH}_{3}$ & 26.1 \\
\hline SintMed20 & $\mathrm{Cl}$ & 28.8 & SintMed24 & $\mathrm{OH}$ & 39.1 \\
\hline SintMed25 & $\mathrm{H}$ & 3.3 & SintMed29 & $\mathrm{Br}$ & 29.8 \\
\hline SintMed26 & $\mathrm{CH}_{3}$ & 35.2 & SintMed30 & $\mathrm{NO}_{2}$ & 0 \\
\hline SintMed27 & $\mathrm{F}$ & 22.7 & SintMed31 & $\mathrm{OCH}_{3}$ & 3.0 \\
\hline SintMed28 & $\mathrm{Cl}$ & 0 & SintMed32 & $\mathrm{OH}$ & 43.8 \\
\hline Mfq & - & 100 & - & - & - \\
\hline
\end{tabular}

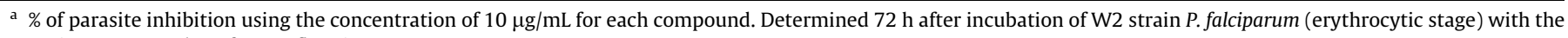
respective compounds. $\mathrm{Mfq}=$ mefloquine.

The five active compounds were submitted to the evaluation of their in vitro potency against $P$. falciparum, and the standard drug mefloquine was used as a reference parameter, as shown in Table 2. Mefloquine exhibited an $\mathrm{IC}_{50}$ value of $0.04 \pm 0.01 \mu \mathrm{M}$. In comparison to mefloquine, vanillinyl moiety-bearing derivatives of $\mathrm{N}$-acylhydrazone-1,2,4-oxadiazole SintMed2 (4-mehylsubstituted), SintMed5 (4-bromosubstituted) and SintMed6 (4-nitrosubstituted) displayed potent anti-P. falciparum activities. While compound SintMed5 was found to be almost as potent as mefloquine with $\mathrm{IC}_{50}$ of $0.07 \pm 0.12 \mu \mathrm{M}$, the other two analogues SintMed2 and SintMed6 were less potent, but still exhibited expressive activities: $\quad 0.12 \pm 0.16 \mu \mathrm{M}$ and $0.20 \pm 0.16 \mu \mathrm{M}$, respectively. Replacement by 4-hydroxyl SintMed8 decreased potency of the final compound. This revealed the importance of a specific substituent located in the phenyl ring attached to the 1,2,4-oxadiazole group, suggesting that lipophilic groups can be more successful in further planning of antimalarial compounds based on this structural features. In Table 2, the lipophilicity parameters $(\log P)$ for the five active compounds are given, evidencing that the more potent compounds present higher lipophilicity in the studied

Table 2

In vitro potency, cytotoxicity, selectivity and $\log P$

\begin{tabular}{|c|c|c|c|c|}
\hline Compounds & P. falciparum $\mathrm{IC}_{50} \pm \mathrm{SD}(\mu \mathrm{M})^{\mathrm{a}}$ & HepG2 $\mathbf{C C}_{\mathbf{5 0}} \pm \mathrm{SD}(\mu \mathrm{M})^{\mathrm{b}}$ & $\mathrm{SI}^{\mathrm{C}}$ & $\log P^{\mathrm{d}}$ \\
\hline SintMed2 & $0.12 \pm 0.16$ & $46.6 \pm 0.5$ & 388 & 3.00 \\
\hline SintMed5 & $0.07 \pm 0.12$ & $16.9 \pm 1.9$ & 241 & 3.36 \\
\hline SintMed6 & $0.20 \pm 0.16$ & $14.8 \pm 0.8$ & 74 & 2.50 \\
\hline SintMed8 & $1.9 \pm 0.8$ & $>200$ & - & 2.07 \\
\hline SintMed16 & $1.5 \pm 1.09$ & $>200$ & - & 2.62 \\
\hline $\mathrm{Mfq}$ & $0.04 \pm 0.01$ & $11.8 \pm 0.3$ & 295 & - \\
\hline
\end{tabular}

a Determined $48 \mathrm{~h}$ after incubation with the drugs.

b Determined $72 \mathrm{~h}$ after incubation with the drugs.

c $\mathrm{SI}$ was determined by the ratio $\mathrm{CC}_{50} / \mathrm{IC}_{50}$. $\mathrm{IC}_{50}$ and $\mathrm{CC}_{50}$ values were determined from two independent experiments using each concentration in triplicate.

$\mathrm{IC}_{50}=$ inhibitory concentration to $50 \% . \mathrm{CC}_{50}=$ cytotoxic concentration to $50 \%$. SD $=$ standard deviation. Mfq $=$ Mefloquine.

${ }^{\mathrm{d}}$ Determined using the online version of the Molinspiration Cheminformatics software (http://www.molinspiration.com/). 
group. The only one active compound derived from the 1,3-benzodioxole series SintMed (9-16), the 4-hydroxylphenyl substituted analogue SintMed16, displayed potency similar to SintMed8.

Next, the cytotoxicity against mammalian HepG2 cells was tested and expressed as $\mathrm{CC}_{50}$ values, as well as the selectivity index (SI), both results described in Table 2. Comparing to mefloquine, which displayed $\mathrm{CC}_{50}$ value of $11.8 \pm 0.3 \mu \mathrm{M}$, none of the studied compounds was more cytotoxic. Compounds SintMed8 and SintMed16 were several folds less cytotoxic than mefloquine, while the other compounds were similarly cytotoxic. Mefloquine had an SI of 295, and compounds SintMed2 $(\mathrm{SI}=388)$ and SintMed5 $(\mathrm{SI}=241)$ revealed a similar selectivity, reinforcing the evidences that lipophilic groups are important for the antimalarial activity, especially when the SI of 74 for SintMed6 is taken into account. The nitro group possesses clearly hydrophilic properties, affecting the activity and selectivity of SintMed6. Although SI for SintMed8 and SintMed16 could not be precisely determined due to lack cytotoxicity against HepG2 cells, it is estimated that they are selective antiparasitic agents.

In addition to the cytotoxicity in HepG2 cells, the percentage of hemolysis in uninfected erythrocytes was determined. As can be seen in Table 3, except for compound SintMed5, which caused hemolysis in the tested concentrations, none of the compounds did it. Again, the nature of the bromine atom attached to the molecule plays an important role for its biological response. The ability of active compounds to inhibit the hemin polymerization into $\beta$-hematin was studied. In this assay (Table 3 ), chloroquine displayed an $\mathrm{IC}_{50}$ of $0.84 \pm 0.30 \mathrm{mM}$. Compounds SintMed2, SintMed5 and SintMed16 inhibited $\beta$-hematin in the tested concentrations with $\mathrm{IC}_{50}$ similar to chloroquine, while compounds SintMed6 and SintMed8 did not. The CQ index indicates the potency of each compound in comparison with chloroquine.

Finally, it was examined the ability of the most potent antimalarial derivatives, compounds SintMed2, SintMed5 and SintMed6, to decrease parasitemia and increase survival in $P$. berghei-infected mice. After $1 \mathrm{~h}$ of infection with NK65 strain, mice were treated orally by gavage or intraperitoneal injection once a day during 4 consecutive days. As can be seen in Figure 4, untreated infected group shows parasitemia, which usually peaks at 6-8 days post infection. By comparison with the untreated group, chloroquine given orally at $50 \mathrm{mg} / \mathrm{kg} /$ day decreases parasitemia $(p<0.001)$ and provides $100 \%$ animal survival $(p<0.05)$ after 30 days of infection. Under oral treatment with compounds SintMed2 and SintMed5 at $100 \mathrm{mg} / \mathrm{kg} /$ day, no parasitemia reduction was detected, and death was observed in less than 30 days (Fig. 4). Even the intraperitoneal administration of compounds SintMed2 and SintMed5 at $100 \mathrm{mg} / \mathrm{kg} /$ day did not lead to better outcomes (data not shown).

In contrast, intraperitoneal treatment with compound SintMed6 dosed at $50 \mathrm{mg} / \mathrm{kg} /$ day and $25 \mathrm{mg} / \mathrm{kg} /$ day decreased parasitemia $(p<0.001)$ in both cases, consisting in a very important experimental result (Fig. 5). Unfortunately, mice survival under such conditions was not so successful, although

Table 3

Hemolytic property, $\beta$-hematin formation inhibition and CQ-index

\begin{tabular}{llll}
\hline Compounds & $\begin{array}{l}\text { Hemolysis } \mathrm{CC}_{50} \pm \mathrm{SD}(\mu \mathrm{g} / \\
\mathrm{mL})^{\mathrm{a}}\end{array}$ & $\begin{array}{l}\beta \text {-Hematin } \mathrm{IC}_{50} \pm \mathrm{SD} \\
(\mathrm{mM})\end{array}$ & $\begin{array}{l}\mathrm{CQ} \\
\text { index }^{\mathrm{b}}\end{array}$ \\
\hline SintMed2 & $>100$ & $0.6 \pm 0.2$ & 1.3 \\
SintMed5 & $33.0 \pm 0.1$ & $0.9 \pm 0.03$ & 0.8 \\
SintMed6 & $>100$ & $>2.0$ & - \\
SintMed8 & $>100$ & $>2.0$ & - \\
SintMed16 & $>100$ & $0.8 \pm 0.5$ & 1.0 \\
$\mathrm{CQ}$ & $>100$ & $0.8 \pm 0.3$ & - \\
\hline
\end{tabular}

${ }^{\text {a }}$ Hemolysis was assayed in uninfected human erythrocytes (type $\mathrm{O}^{+}$) after $1 \mathrm{~h}$ of incubation with compounds, in triplicate.

${ }^{b}$ Determined by the ratio $\mathrm{IC}_{50} \mathrm{CQ} / \mathrm{IC}_{50}$ test compound. $\mathrm{CQ}=$ Chloroquine.
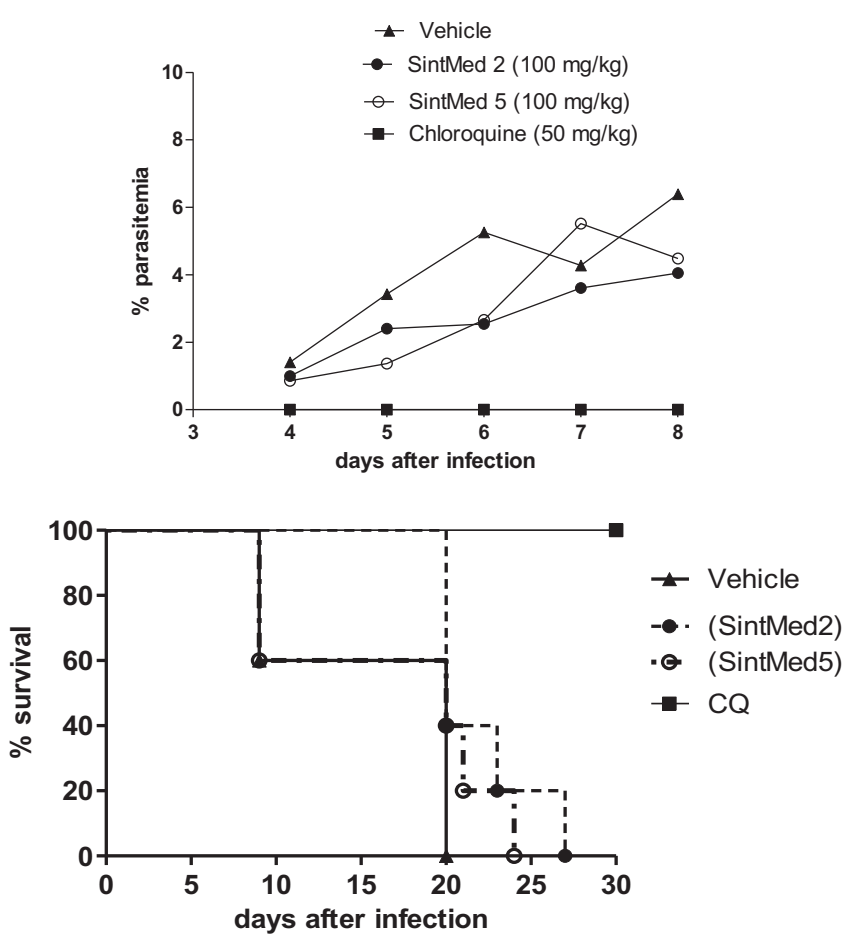

Figure 4. (Top) Blood parasitemia and (Bottom) \% survival of $P$. berghei-infected mice. Swiss mice ( $n=5$ /group) were infected with NK65 strain and $1 \mathrm{~h}$ after, treated once a day for four consecutive days. Vehicle group received 10\% DMSO in saline. Values represent the means \pm SEM of five mice per group in one experiment of two replicates performed. $\mathrm{CQ}=$ chloroquine. i.p. $=$ intraperitoneal injection. p.o. $=$ oral (gavage). Top: vehicle vs CQ (one-way ANOVA, $p<0.001$ ). Bottom: vehicle vs CQ (Mantel-Cox test, $p<0.05)$.
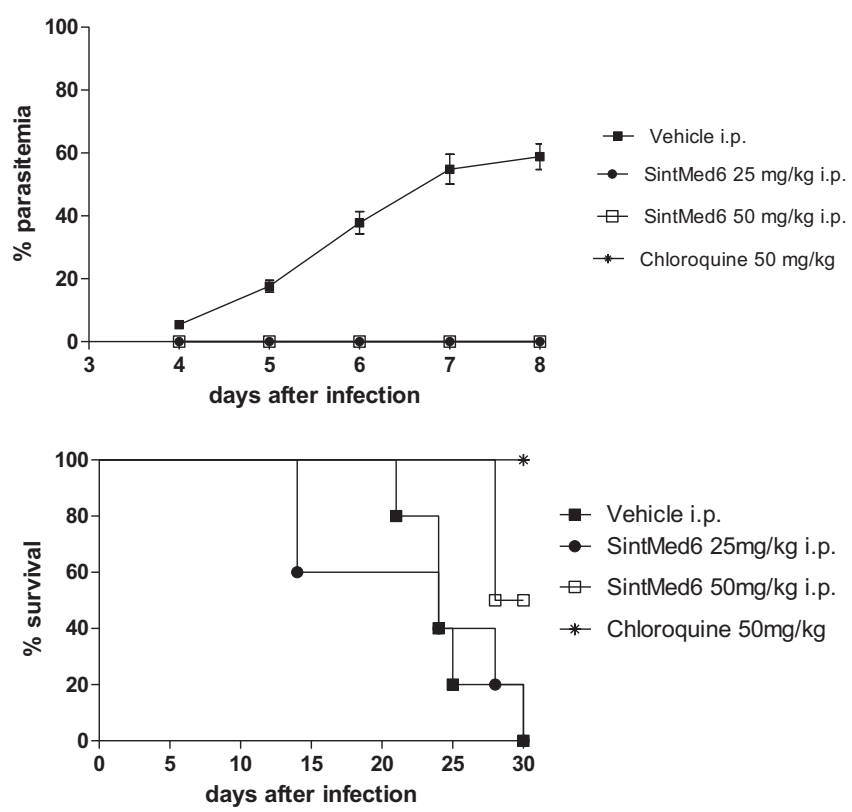

Figure 5. (Top) Blood parasitemia and (Bottom) \% survival of $P$. berghei-infected mice. Swiss mice ( $n=5 /$ group) were infected with NK65 strain and $1 \mathrm{~h}$ after, treated once a day for four consecutive days. Vehicle group received 10\% DMSO in saline. Values represent the means \pm SEM of five mice per group in one experiment of two replicates performed. $\mathrm{CQ}=$ chloroquine. i.p. $=$ intraperitoneal injection. p.o. $=$ oral (gavage). Top: vehicle vs CQ (one-way ANOVA, $p<0.001$ ), vehicle vs (SintMed6) $25 \mathrm{mg} / \mathrm{kg}$ (one-way ANOVA, $p<0.01$ ), vehicle vs (SintMed6) $50 \mathrm{mg} / \mathrm{kg}$ (one-way ANOVA, $p<0.001$ ). Bottom: vehicle vs CQ (Mantel-Cox test, $p<0.05$ ). 
an improvement could be registered, reinforcing our initial assumptions about the importance of the 1,2,4-oxadiazole- $N$-acylhydrazone backbone structure as a pattern for the design and development of potential new antiparasitics of high efficacy.

\section{Conclusion}

Here, new antimalarial compounds were identified on the basis of structural design by employing hybridization between 1,2,4oxadiazole, $\mathrm{N}$-acylhydrazone and natural or synthetic occurring relevant biological groups. Antimalarial activity was observed to be quite dependent on the vanillinyl moiety attached to the iminic structure, whose biological response for the active derivatives seems to be dependent on the lipophilicity of the substituents linked to the 4-position of the phenyl ring attached to the oxadiazole portion. This structural design successfully led to the identification of compounds SintMed2, SintMed5 and SintMed6 as potent and selective anti- $P$. falciparum agents, as similarly observed in mefloquine-treated parasites. Mechanistically, these compounds did show general inhibitory properties for $\beta$-hematin formation, suggesting that they present a mechanism of action similar to that of quinoline based drugs, which are well-known $\beta$-hematin inhibitors. Therefore, the collected data suggest that the molecular hybridization is a promising line of research for structural modification targeting antiparasitic agents based on 1,2,4-oxadiazole- $N$ acylhydrazone association.

\section{Experimental section}

\subsection{Chemistry}

All solvents and reactants were purchased from Sigma-Aldrich, Fluka, Vetec and Acros Chemicals, and were used without further purification. Reactions' progresses were monitored by thin layer chromatography (TLC), performed onto glass-backed plates of silica gel 60 F254 with gypsum, and all compounds were detected by ultraviolet light $(254 \mathrm{~nm})$. Melting points were determined with a capillary apparatus Gehaka PF 1500 Farma and are uncorrected. NMR spectra were recorded at $400 \mathrm{MHz}$ for hydrogen and $100 \mathrm{MHz}$ for carbon, using a Varian UNMRS 400 spectrometer, or at $300 \mathrm{MHz}$ for hydrogen and $75 \mathrm{MHz}$ for carbon nuclei, using a Varian Unitplus 300 NMR. Analyses were determined in DMSO- $d_{6}$ with chemical shift values $(\delta)$ in parts per million (ppm) and coupling constants $(J)$ in Hertz $(\mathrm{Hz})$, and measured at $25{ }^{\circ} \mathrm{C} .{ }^{1} \mathrm{H}$ and ${ }^{13} \mathrm{C}$ assignments were assisted by $2 \mathrm{D}$ experiments, such as DEPT full edit, HMBC and HSQC. IR spectra were recorded on a Tensor27 FTIR spectrometer from Bruker with the samples being analyzed as $\mathrm{KBr}$ pellets. High resolution mass spectrometry (HRMS) analysis of the pure compounds was performed with an UHPLC-ESI-HRMS on a Micromass LCT Premier time-of-flight mass spectrometer from Waters with an electrospray ionization (ESI) interface (Waters, Milford, MA, USA) equipped with an electrospray interface and coupled to an Acquity UHPLC system (Waters, Milford MA, USA). UHPLC-ESI-HRMS analysis was performed using the following parameters: ESI used capillary voltage $2800 \mathrm{~V}$, cone voltage $40 \mathrm{~V}$, MCP detector voltage $2400 \mathrm{~V}$, source temperature $120^{\circ} \mathrm{C}$, desolvation temperature $300{ }^{\circ} \mathrm{C}$, cone gas flow $20 \mathrm{~L} / \mathrm{h}$, and desolvation gas flow $800 \mathrm{~L} / \mathrm{h}$. Detection was performed in positive ion mode (PI) with a $m / z$ range of $100-1300 \mathrm{Da}$ and a scan time of $0.5 \mathrm{~s}$ in the $\mathrm{W}$-mode. The MS was calibrated using sodium formate, and leucine encephalin (Sigma-Aldrich, Steinheim, Germany) was used as an internal reference at $2 \mu \mathrm{g} / \mathrm{mL}$ and infused through a Lock Spray $^{\mathrm{TM}}$ probe at a flow rate of $10 \mu \mathrm{L} / \mathrm{min}$ with the help of a second LC pump. The separation was performed on an Acquity BEH $\mathrm{C}_{18}$ UPLC column $(1.7 \mu \mathrm{m}, 50 \times 2.1 \mathrm{~mm}$ i.d.; Waters, Milford, MA,
USA) using a linear gradient, solvent system: (A) $0.1 \%$ formic acid-water, (B) $0.1 \%$ formic acid-acetonitrile; gradient: $5-36 \% \mathrm{~B}$ in $1 \mathrm{~min}$, then $36 \% \mathrm{~B}$ to $36 \% \mathrm{~B}$ in $2 \mathrm{~min}, 36 \% \mathrm{~B}$ to $95 \% \mathrm{~B}$ in $1.5 \mathrm{~min}$; flow rate $1.1 \mathrm{~mL} / \mathrm{min}$. The temperature was set to $40^{\circ} \mathrm{C}$. The injected volume was kept constant $(1 \mu \mathrm{L}$; solution at the concentration of $0.5 \mathrm{mg} / \mathrm{mL}$ ). Elemental analyses were performed in a Perkin Elmer 2400 Series II elemental analyzer.

\subsubsection{Preparation of compounds SintMed (1-32)}

To a stirred suspension of $1 \mathrm{mmol}$ of appropriate hydrazide and $1 \mathrm{mmol}$ of aldehyde in $10 \mathrm{~mL}$ of ethanol $10 \mathrm{~mol} \%$ cerium(III) chloride heptahydrate was added and the reaction mixture was stirred at $40^{\circ} \mathrm{C}$ during $10-30 \mathrm{~min}$. Reaction's completion was monitored by TLC, using ethyl acetate as eluent system. Once concluded, the heating was put away, and $20 \mathrm{~mL}$ of water was added to the medium. After standing at refrigerator, vacuum filtration was carried out, and the solid was washed with cold water/ethanol 1:1 followed by cold water. ${ }^{1} \mathrm{H}$ NMR analysis of all crude products confirmed their purity. Recrystallization from dioxane/water mixture afforded the pure products for biological purposes. Yields, melting points, spectroscopic and spectrometric data are listed below for each new compound.

4.1.1.1. 3-Phenyl- $N^{\prime}$-[(1E,2E)-3-phenylprop-2-en-1-ylideno]-1,2, 4-oxadiazol-5-ylcarbohydrazide SintMed17. Yield: 90\%; Mp 167.6-170-2 ${ }^{\circ} \mathrm{C}$ (from dioxane $\left./ \mathrm{H}_{2} \mathrm{O}\right)$; IR $\left(\mathrm{KBr}, v_{\max } \mathrm{cm}^{-1}\right)$ : 3266 $(\mathrm{NH}), 3090(\mathrm{Ar} \mathrm{CH}), 1700(\mathrm{C}=\mathrm{O}), 1625(\mathrm{C}=\mathrm{N}$, imine $), 1529(\mathrm{C}=\mathrm{N}$, heterocyclic); ${ }^{1} \mathrm{H}$ NMR (300 MHz, DMSO- $\left.d_{6}\right) \delta$, ppm: $12.7(\mathrm{~s}, 1 \mathrm{H}$, CONH $), 8.42\left(\mathrm{~d}, 1 \mathrm{H},{ }^{3} \mathrm{~J}=8.1 \mathrm{~Hz}, \mathrm{~N}=\mathrm{CH}\right), 8.10\left(\mathrm{~d}, 2 \mathrm{H},{ }^{3} \mathrm{~J}=7.8 \mathrm{~Hz}, \mathrm{Ph}\right.$ $\mathrm{H}-2,6), 7.67-7.59$ ( $\mathrm{m}, 5 \mathrm{H}, \mathrm{Ph} \mathrm{H}-3,4,5$ and Cinnamyl H-2,6), 7.42 $\left(\mathrm{d}, 1 \mathrm{H},{ }^{3} \mathrm{~J}=6.6 \mathrm{~Hz}, \mathrm{CH}=\mathrm{CHPh}\right), 7.37\left(\mathrm{t}, 2 \mathrm{H},{ }^{3} \mathrm{~J}=4.8 \mathrm{~Hz}\right.$, Cinnamyl $\mathrm{H}-3,5), 7.11(\mathrm{~d}, 2 \mathrm{H}, \mathrm{HC}=\mathrm{CHPh}$ and Cinnamyl $\mathrm{H}-4) ;{ }^{13} \mathrm{C}$ NMR (75 MHz, DMSO- $\left.d_{6}\right) \delta$, ppm: $168.7(1 \mathrm{C}, \mathrm{C}=0), 168.1$ (1C, Oxadiazole C-3), 153.5 (1C, C=NH), 149.4 (1C, Oxadiazole C-5), 141.3 (1C, $\mathrm{CH}=\mathrm{CHPh}$ ), 135.6 (1C, Cinnamyl C-1), 132.0 (1C, Ph C-4), 129.4 (2C, Ph C-3,5), 129.2 (1C, CH=CHAr), 128.8 (2C, Cinnamyl C-3,5), 127.3 (2C, Cinnamyl C-2,6), 127.2 (2C, Ph C-2,6), 125.4 (1C, Ph C1), 125.1 (1C, Cinnamyl C-4); UHPLC-TOF-MS for $\mathrm{C}_{18} \mathrm{H}_{14} \mathrm{~N}_{4} \mathrm{O}_{2}$ calcd (found)/Error: 318.1117 (317.1089, [M-H] $\left.]^{-}\right) / 15.8$ ppm.

4.1.1.2. 3-(4-Tolyl)- $N^{\prime}$-[(1E,2E)-3-phenylprop-2-en-1-ylideno]1,2,4-oxadiazol-5-ylcarbohydrazide SintMed18. Yield: $94 \%$; $\mathrm{Mp}$ 197.1-199.7 ${ }^{\circ} \mathrm{C}$ (from dioxane/ $\left.\mathrm{H}_{2} \mathrm{O}\right)$; IR $\left(\mathrm{KBr}, v_{\max } \mathrm{cm}^{-1}\right): 3232$ (NH), 3058 (Ar CH), $1684(\mathrm{C}=\mathrm{O}), 1622(\mathrm{C}=\mathrm{N}$, imine), $1581(\mathrm{C}=\mathrm{N}$, heterocyclic); ${ }^{1} \mathrm{H}$ NMR (300 MHz, DMSO- $\left.d_{6}\right) \delta, \mathrm{ppm}: 12.7(\mathrm{~s}, 1 \mathrm{H}$, CONH), $8.41\left(\mathrm{~d}, 1 \mathrm{H},{ }^{3} \mathrm{~J}=6.0 \mathrm{~Hz}, \mathrm{~N}=\mathrm{CH}\right), 7.98\left(\mathrm{~d}, 2 \mathrm{H},{ }^{3} \mathrm{~J}=5.7 \mathrm{~Hz}\right.$, Tolyl H-2,6), 7.65 (d, 2H, Cinnamyl H-2,6), 7.43-7.40 (m, 5H, Tolyl $\mathrm{H}-3,5, \mathrm{CH}=\mathrm{CHPh}$ and Cinnamyl H-3,5), 7.13 (d, 2H, $\mathrm{CH}=\mathrm{CHAr}$ and Cinnamyl H-4), $2.39\left(\mathrm{~s}, 3 \mathrm{H}, \mathrm{CH}_{3}\right) ;{ }^{13} \mathrm{C}$ NMR $\left(75 \mathrm{MHz}\right.$, DMSO- $\left.d_{6}\right) \delta$, ppm: 168.5 (1C, C=0), 168.1 (1C, Oxadiazole C-3), 153.4 (1C, $\mathrm{C}=\mathrm{NH}), 149.4$ (1C, Oxadiazole C-5), 142.1 (1C, Tolyl C-4), 141.3 $(1 \mathrm{C}, \mathrm{CH}=\mathrm{CHPh}), 135.6$ (1C, Cinnamyl C-1), 129.9 (2C, Tolyl C-3,5), $129.2(\mathrm{CH}=\mathrm{CHPh}), 128.8$ (2C, Cinnamyl C-3,5), 127.3 (2C, Cinnamyl C-2,6), 127.1 (2C, Tolyl C-2,6), 125.1 (1C, Cinnamyl C-4), 122.7 (1C, Tolyl C-1), 21.1 (1C, $\mathrm{CH}_{3}$ ); UHPLC-TOF-MS for $\mathrm{C}_{19} \mathrm{H}_{16} \mathrm{~N}_{4} \mathrm{O}_{2}$ calcd (found)/Error: $332.1273\left(331.1189,[\mathrm{M}-\mathrm{H}]^{-}\right) / 1.8 \mathrm{ppm}$.

4.1.1.3. 3-(4-Fluorophenyl)- $N^{\prime}-[(1 E, 2 E)-3-p h e n y l p r o p-2-e n-1-$ ylideno]-1,2,4-oxadiazol-5-ylcarbohydrazide SintMed19. Yield: 94\%; Mp 214.4-215.8 ${ }^{\circ} \mathrm{C}$ (from dioxane $/ \mathrm{H}_{2} \mathrm{O}$ ); IR ( $\mathrm{KBr}, v_{\max }$ $\left.\mathrm{cm}^{-1}\right)$ : $3256(\mathrm{NH}), 3058(\mathrm{Ar} \mathrm{CH}), 1685(\mathrm{C}=\mathrm{O}), 1607$ ( $\mathrm{C}=\mathrm{N}$, imine), $1584\left(\mathrm{C}=\mathrm{N}\right.$, heterocyclic); ${ }^{1} \mathrm{H}$ NMR $\left(400 \mathrm{MHz}\right.$, DMSO $\left.-d_{6}\right) \delta$, ppm: $12.7(\mathrm{~s}, 1 \mathrm{H}, \mathrm{CONH}), 8.41$ (d, $\left.1 \mathrm{H},{ }^{3} \mathrm{~J}=8.0 \mathrm{~Hz}, \mathrm{~N}=\mathrm{CH}\right), 8.13$ (dd, $2 \mathrm{H}$, $\left.{ }^{3} J_{F H}=3.2 \mathrm{~Hz},{ }^{3} J_{H H}=8.8 \mathrm{~Hz}, 4-\mathrm{FPh} \mathrm{H}-2,6\right), 7.68\left(\mathrm{~d}, 2 \mathrm{H},{ }^{3} \mathrm{~J}=7.2 \mathrm{~Hz}\right.$, Cinnamyl $\mathrm{H}-2,6), 7.49-7.30(\mathrm{~m}, 5 \mathrm{H}, 4-\mathrm{FPh} \mathrm{H}-3,5, \mathrm{CH}=\mathrm{CHPh}$ and 
Cinnamyl $\mathrm{H}-3,5), 7.18-7.06(\mathrm{~m}, 2 \mathrm{H}, \mathrm{CH}=\mathrm{CHPh}$ and Cinnamyl $\mathrm{H}-4)$; ${ }^{13} \mathrm{C}$ NMR (100 MHz, DMSO- $\left.d_{6}\right) \delta$, ppm: 168.5 (1C, C=0), 167.3 (1C, Oxadiazole C-3), 164.2 (1C, d, $\left.{ }^{1} J_{F C}=249.4 \mathrm{~Hz}, 4 \mathrm{FPh} \mathrm{H}-4\right), 153.5$ (1C, $\mathrm{C}=\mathrm{NH}), 149.4(1 \mathrm{C}$, Oxadiazole $\mathrm{C}-5), 141.3(1 \mathrm{C}, \mathrm{CH}=\mathrm{CHPh}), 135.6$ (1C, Cinnamyl C-1), $129.8\left(2 \mathrm{C}, \mathrm{d},{ }^{3} J_{F C}=9.3 \mathrm{~Hz}, 4-\mathrm{FPh} \mathrm{H}-2,6\right), 129.2$ $(1 \mathrm{C}, \mathrm{CH}=\mathrm{CHPh}$ ), 128.8 (2C, Cinnamyl C-3,5), 127.3 (2C, Cinnamyl C-2,6), 125.1 (1C, Cinnamyl C-4), 122.0 (1C, d, ${ }^{4} J_{F C}=3.1 \mathrm{~Hz}, 4-\mathrm{FPh}$ $\mathrm{H}-1), 116.6\left(2 \mathrm{C}, \mathrm{d},{ }^{2} J_{F C}=21.7 \mathrm{~Hz}, 4 \mathrm{FPh} \mathrm{H}-3,5\right)$; UHPLC-TOF-MS for $\mathrm{C}_{18} \mathrm{H}_{13} \mathrm{~N}_{4} \mathrm{O}_{2} \mathrm{~F}$ calcd (found)/Error: 336.1022 (335.0986, $\left.\left[\mathrm{M}-\mathrm{H}^{-}\right]\right) / 12.5$ ppm.

4.1.1.4. 3-(4-Chlorophenyl)- $N^{\prime}-[(1 E, 2 E)-3-p h e n y l p r o p-2-e n-1-$ ylideno]-1,2,4-oxadiazol-5-ylcarbohydrazide SintMed20. Yield: 91\%; Mp 214.7-216.6 ${ }^{\circ} \mathrm{C}$ (from dioxane/ $\mathrm{H}_{2} \mathrm{O}$ ); IR ( $\mathrm{KBr}, v_{\max }$ $\left.\mathrm{cm}^{-1}\right)$ : $3226(\mathrm{NH}), 3055(\mathrm{Ar} \mathrm{CH}), 1688(\mathrm{C}=\mathrm{O}), 1619(\mathrm{C}=\mathrm{N}$, imine $)$, 1589 ( $\mathrm{C}=\mathrm{N}$, heterocyclic); ${ }^{1} \mathrm{H}$ NMR $\left(300 \mathrm{MHz}, \mathrm{DMSO}-d_{6}\right) \delta$, ppm: $12.7(\mathrm{~s}, 1 \mathrm{H}, \mathrm{CONH}), 8.40\left(\mathrm{~d}, 1 \mathrm{H},{ }^{3} \mathrm{~J}=8.1 \mathrm{~Hz}, \mathrm{~N}=\mathrm{CH}\right), 8.09(\mathrm{~d}, 2 \mathrm{H}$, $\left.{ }^{3} \mathrm{~J}=8.7 \mathrm{~Hz}, 4 \mathrm{ClPh} \mathrm{H}-2,6\right), 7.69\left(\mathrm{~d}, 2 \mathrm{H},{ }^{3} \mathrm{~J}=5.1 \mathrm{~Hz}, 4-\mathrm{ClPh} \mathrm{H}-3,5\right)$, $7.65\left(\mathrm{~d}, 2 \mathrm{H},{ }^{3} \mathrm{~J}=8.7 \mathrm{~Hz}\right.$, Cinnamyl H-2,6), $7.42\left(\mathrm{~d}, 1 \mathrm{H},{ }^{3} \mathrm{~J}=6.6 \mathrm{~Hz}\right.$, $\mathrm{CH}=\mathrm{CHPh}), 7.36\left(\mathrm{t}, 2 \mathrm{H},{ }^{3} \mathrm{~J}=4.2 \mathrm{~Hz}\right.$, Cinnamyl H-3,5), $7.11(2 \mathrm{xs}$, $2 \mathrm{H}, \mathrm{CH}=\mathrm{CHPh}$ and Cinnamyl $\mathrm{H}-4) ;{ }^{13} \mathrm{C}$ NMR $\left(75 \mathrm{MHz}\right.$, DMSO- $\left.d_{6}\right)$ $\delta$, ppm: 168.8 (1C, $\mathrm{C}=0$ ), 167.3 (1C, Oxadiazole C-3), 153.5 (1C, $\mathrm{C}=\mathrm{NH}$ ), 149.3 (1C, Oxadiazole $\mathrm{C}-5), 141.3(1 \mathrm{C}, \mathrm{CH}=\mathrm{CHPh}), 136.8$ (1C, 4-ClPh C-4), 135.6 (1C, Cinnamyl C-1), 129.6 (2C, 4-ClPh C3,5), 129.3 (2C, 4-ClPh C-2,6), 129.1 (1C, HC=CHPh), 129.0 (2C, Cinnamyl C-3,5), 127.4 (2C, Cinnamyl C-2,6), 125.1 (1C, Cinnamyl C-4), 124.3 (1C, 4-ClPh C-1); UHPLC-TOF-MS for $\mathrm{C}_{18} \mathrm{H}_{13} \mathrm{ClN}_{4} \mathrm{O}_{2}$ calcd (found)/Error: 352.0727 (351.0622, $\left.\left[\mathrm{M}-\mathrm{H}^{-}\right]\right) / 7.7 \mathrm{ppm}$.

4.1.1.5. 3-(4-Bromophenyl)- $N^{\prime}-[(1 E, 2 E)-3-p h e n y l p r o p-2-e n-1-$ ylideno]-1,2,4-oxadiazol-5-ylcarbohydrazide SintMed21. Yield: 89\%; Mp 195.6-198.3 ${ }^{\circ} \mathrm{C}$ (from dioxane $/ \mathrm{H}_{2} \mathrm{O}$ ); IR (KBr, $v_{\max }$ $\left.\mathrm{cm}^{-1}\right)$ : $3426(\mathrm{NH}), 3055(\mathrm{Ar} \mathrm{CH}), 1689(\mathrm{C}=\mathrm{O}), 1624(\mathrm{C}=\mathrm{N}$, imine $)$, $1543\left(\mathrm{C}=\mathrm{N}\right.$, heterocyclic); ${ }^{1} \mathrm{H}$ NMR $\left(400 \mathrm{MHz}\right.$, DMSO- $\left.d_{6}\right) \delta$, ppm: $12.7(\mathrm{~s}, 1 \mathrm{H}, \mathrm{CONH}), 8.41\left(\mathrm{~d}, 1 \mathrm{H},{ }^{3} \mathrm{~J}=8.0 \mathrm{~Hz}, \mathrm{~N}=\mathrm{CH}\right), 8.02(\mathrm{~d}, 2 \mathrm{H}$, $\left.{ }^{3} \mathrm{~J}=8.4 \mathrm{~Hz}, 4-\mathrm{BrPh} \mathrm{H}-2,6\right), 7.84$ (d, $\left.2 \mathrm{H},{ }^{3} \mathrm{~J}=8.4 \mathrm{~Hz}, 4-\mathrm{BrPh} \mathrm{H}-3,5\right)$, $7.66\left(\mathrm{~d}, 2 \mathrm{H},{ }^{3} \mathrm{~J}=7.2 \mathrm{~Hz}\right.$, Cinnamyl H-2,6), $7.42\left(\mathrm{~d}, 1 \mathrm{H},{ }^{3} \mathrm{~J}=7.2 \mathrm{~Hz}\right.$, $\mathrm{CH}=\mathrm{CHAr}), 7.37\left(\mathrm{t}, 2 \mathrm{H},{ }^{3} \mathrm{~J}=7.6 \mathrm{~Hz}\right.$, Cinnamyl $\left.\mathrm{H}-3,5\right), 7.17-7.06$ $(\mathrm{m}, 2 \mathrm{H}, \mathrm{CH}=\mathrm{CHPh}$ and Cinnamyl $\mathrm{H}-4) ;{ }^{13} \mathrm{C}$ NMR $(100 \mathrm{MHz}$, DMSO- $\left.d_{6}\right) \delta$, ppm: $168.8(1 \mathrm{C}, \mathrm{C}=\mathrm{O}), 167.4$ (1C, Oxadiazole C-3), $153.6(1 \mathrm{C}, \mathrm{C}=\mathrm{NH}), 149.3$ (1C, Oxadiazole $\mathrm{C}-5), 141.3$ (1C, $\mathrm{CH}=\mathrm{CHPh}), 135.6(1 \mathrm{C}$, Cinnamyl C-1), 132.5 (2C, 4BrPh C-3,5), 129.3 (2C, 4-BrPh C-2,6), $129.2(1 \mathrm{C}, \mathrm{CH}=\mathrm{CHPh}), 128.8$ (2C, Cinnamyl C-3,5), 127.4 (2C, Cinnamyl C-2,6), 125.7 (1C, 4-BrPh C-4), 125.1 (1C, Cinnamyl C-4), 124.7 (1C, 4-BrPh C-1); UHPLC-TOF-MS for $\mathrm{C}_{18} \mathrm{H}_{13} \mathrm{BrN}_{4} \mathrm{O}_{2}$ calcd (found)/Error: 396.0222 (395.0160, $\left.\left[\mathrm{M}-\mathrm{H}^{-}\right]\right) / 4.1 \mathrm{ppm}$.

4.1.1.6. 3-(4-Nitrophenyl)- $N^{\prime}-[(1 E, 2 E)-3-p h e n y l p r o p-2-e n-1-y l i-$ deno]-1,2,4-oxadiazol-5-ylcarbohydrazide SintMed22. Yield: 91\%; Mp 235.5-238. ${ }^{\circ} \mathrm{C}$ (from dioxane $/ \mathrm{H}_{2} \mathrm{O}$ ); IR ( $\mathrm{KBr}, v_{\max }$ $\left.\mathrm{cm}^{-1}\right)$ : $3210(\mathrm{NH}), 3075(\mathrm{Ar} \mathrm{CH}), 1708(\mathrm{C}=\mathrm{O}), 1620(\mathrm{C}=\mathrm{N}$, imine), 1569 (C=N, heterocyclic); ${ }^{1} \mathrm{H}$ NMR $\left(300 \mathrm{MHz}\right.$, DMSO- $\left.d_{6}\right) \delta$, ppm: $12.8(\mathrm{~s}, 1 \mathrm{H}, \mathrm{CONH}), 8.44$ (d, $\left.2 \mathrm{H},{ }^{3} \mathrm{~J}=8.7 \mathrm{~Hz}, 4-\mathrm{NO}_{2} \mathrm{Ph} \mathrm{H}-3,5\right), 8.40$ $\left(\mathrm{d}, 1 \mathrm{H},{ }^{3} \mathrm{~J}=7.8 \mathrm{~Hz}, \mathrm{~N}=\mathrm{CH}\right), 8.32\left(\mathrm{~d}, 2 \mathrm{H},{ }^{3} \mathrm{~J}=9.0 \mathrm{~Hz}, 4-\mathrm{NO}_{2} \mathrm{Ph} \mathrm{H}-\right.$ 2,6), 7.67 (d, 2H, ${ }^{3} \mathrm{~J}=7.2 \mathrm{~Hz}$, Cinnamyl H-2,6), 7.41 (d, $1 \mathrm{H}$, $\left.{ }^{3} \mathrm{~J}=7.2 \mathrm{~Hz}, \mathrm{CH}=\mathrm{CHPh}\right), 7.36\left(\mathrm{t}, 2 \mathrm{H},{ }^{3} \mathrm{~J}=6.0 \mathrm{~Hz}\right.$, Cinnamyl $\left.\mathrm{H}-3,5\right)$, $7.12(\mathrm{~m}, 2 \mathrm{H}, \mathrm{CH}=\mathrm{CHPh}$ and Cinnamyl $\mathrm{H}-4) ;{ }^{13} \mathrm{C} \mathrm{NMR}(75 \mathrm{MHz}$, DMSO- $\left.d_{6}\right) \delta$, ppm: $169.1(1 \mathrm{C}, \mathrm{C}=0), 166.8$ (1C, Oxadiazole C-3), $153.6(1 \mathrm{C}, \mathrm{C}=\mathrm{NH}), 149.4\left(1 \mathrm{C}, 4-\mathrm{NO}_{2} \mathrm{Ph} \mathrm{C}-4\right), 149.1$ (1C, Oxadiazole C-5), 141.3 (1C, HC=CHPh), 135.5 (1C, Cinnamyl C-1), 131.2 (1C, 4$\left.\mathrm{NO}_{2} \mathrm{Ph} \mathrm{C}-1\right), 129.3(1 \mathrm{C}, \mathrm{HC}=\mathrm{CHAr}), 128.8$ (2C, Cinnamyl C-3,5), 128.6 (2C, 4- $\left.\mathrm{NO}_{2} \mathrm{Ph} \mathrm{C}-2,6\right), 127.3$ (4C, Cinnamyl C-2,6), 125.0 (1C, Cinnamyl C-4), 124.6 (2C, 4- $\mathrm{NO}_{2} \mathrm{Ph}$ C-3,5); UHPLC-TOF-MS for $\mathrm{C}_{18} \mathrm{H}_{13} \mathrm{~N}_{5} \mathrm{O}_{4}$ : $[\mathrm{M}-\mathrm{H}]^{-} 363.0968$ calcd (found)/Error: (362.0908, $\left.\left[\mathrm{M}-\mathrm{H}^{-}\right]\right) / 5.2 \mathrm{ppm}$.
4.1.1.7. 3-(4-Methoxyphenyl)- $N^{\prime}-[(1 E, 2 E)$-3-phenylprop-2-en-1ylideno]-1,2,4-oxadiazol-5-ylcarbohydrazide SintMed23. Yield: 96\%; Mp 185.8-188.2 ${ }^{\circ} \mathrm{C}$ (from dioxane $/ \mathrm{H}_{2} \mathrm{O}$ ); IR (KBr, $v_{\max }$ $\left.\mathrm{cm}^{-1}\right)$ : $3203(\mathrm{NH}), 3055(\mathrm{Ar} \mathrm{CH}), 1698(\mathrm{C}=\mathrm{O}), 1618(\mathrm{C}=\mathrm{N}$, imine), 1597 ( $\mathrm{C}=\mathrm{N}$, heterocyclic); ${ }^{1} \mathrm{H}$ NMR $\left(300 \mathrm{MHz}\right.$, DMSO- $\left.d_{6}\right) \delta$, ppm: $12.7(\mathrm{~s}, 1 \mathrm{H}, \mathrm{CONH}), 8.41\left(\mathrm{~d}, 1 \mathrm{H},{ }^{3} \mathrm{~J}=8.4 \mathrm{~Hz}, \mathrm{~N}=\mathrm{CH}\right), 8.03(\mathrm{~d}, 2 \mathrm{H}$, $\left.{ }^{3} \mathrm{~J}=8.7 \mathrm{~Hz}, 4-\mathrm{MeOPh} \mathrm{H}-2,6\right), 7.65\left(\mathrm{~d}, 2 \mathrm{H},{ }^{3} \mathrm{~J}=6.9 \mathrm{~Hz}\right.$, Cinnamyl H2,6), $7.41\left(\mathrm{~d}, 1 \mathrm{H},{ }^{3} \mathrm{~J}=7.2 \mathrm{~Hz}, \mathrm{CH}=\mathrm{CHPh}\right), 7.36\left(\mathrm{t}, 2 \mathrm{H},{ }^{3} \mathrm{~J}=3.6 \mathrm{~Hz}\right.$, Cinnamyl H-3,5), $7.16\left(\mathrm{~d}, 1 \mathrm{H},{ }^{3} J=6.9 \mathrm{~Hz}, \mathrm{CH}=\mathrm{CHPh}\right), 7.14-7.10(\mathrm{~m}, 3 \mathrm{H}$, 4-MeOPh H-3,5 and Cinnamyl H-4), $3.85\left(\mathrm{~s}, 3 \mathrm{H}, \mathrm{OCH}_{3}\right) ;{ }^{13} \mathrm{C}$ NMR (75 MHz, DMSO- $d_{6}$ ) $\delta$, ppm: $168.4(1 \mathrm{C}, \mathrm{C}=\mathrm{O}), 167.8$ (1C, Oxadiazole C-3), 162.0 (1C, 4-MeOPh C-4), 153.5 (1C, C=NH), 149.5 (1C, Oxadiazole C-5), 141.2 (1C, HC=CHPh), 135.6 (1C, Cinnamyl C-1), 129.2 $(1 \mathrm{C}, \mathrm{HC}=\mathrm{CHPh}), 129.0$ (2C, 4-MeOPh C-2,6), 128.8 (2C, Cinnamyl C3,5), 127.3 (2C, Cinnamyl C-2,6), 125.1 (1C, Cinnamyl C-4), 117.6 (1C, 4-MeOPh C-1), 114.8 (2C, 4-MeOPh C-3,5), $55.4\left(\mathrm{C}, \mathrm{OCH}_{3}\right)$; UHPLC-TOF-MS for $\mathrm{C}_{19} \mathrm{H}_{16} \mathrm{~N}_{4} \mathrm{O}_{3}$ calcd (found)/Error: 348.1223 $\left(347.1107,[\mathrm{M}-\mathrm{H}]^{-}\right) / 10.7 \mathrm{ppm}$.

4.1.1.8. 3-(4-Hydroxyphenyl)- $N^{\prime}-[(1 E, 2 E)-3-p h e n y l p r o p-2-e n-1-$ ylideno]-1,2,4-oxadiazol-5-ylcarbohydrazide SintMed24. Yield: 92\%; Mp $170.3-171.7^{\circ} \mathrm{C}$ (from dioxane $/ \mathrm{H}_{2} \mathrm{O}$ ); IR (KBr, $v_{\max }$ $\left.\mathrm{cm}^{-1}\right)$ : $3426(\mathrm{OH}), 3260(\mathrm{NH}), 3054(\mathrm{Ar} \mathrm{CH}), 1690(\mathrm{C}=\mathrm{O}), 1624$ ( $\mathrm{C}=\mathrm{N}$, imine), $1531\left(\mathrm{C}=\mathrm{N}\right.$, heterocyclic); ${ }^{1} \mathrm{H}$ NMR $(300 \mathrm{MHz}$, DMSO- $\left.d_{6}\right) \delta$, ppm: $12.7(\mathrm{~s}, 1 \mathrm{H}, \mathrm{CONH}), 10.3(\mathrm{~s}, 1 \mathrm{H}, \mathrm{OH}), 8.41(\mathrm{~d}$, $\left.1 \mathrm{H},{ }^{3} \mathrm{~J}=7.5 \mathrm{~Hz}, \mathrm{~N}=\mathrm{CH}\right), 7.93\left(\mathrm{~d}, 2 \mathrm{H},{ }^{3} \mathrm{~J}=9.0 \mathrm{~Hz}, 4-\mathrm{OHPh} \mathrm{H}-2,6\right)$, $7.65\left(\mathrm{~d}, 2 \mathrm{H},{ }^{3} \mathrm{~J}=7.2 \mathrm{~Hz}\right.$, cinnamyl $\left.\mathrm{H}-2,6\right), 7.41\left(\mathrm{~d}, 1 \mathrm{H},{ }^{3} \mathrm{~J}=6.3 \mathrm{~Hz}\right.$, $\mathrm{HC}=\mathrm{CHPh}), 7.36\left(\mathrm{t}, 2 \mathrm{H},{ }^{3} \mathrm{~J}=6.3 \mathrm{~Hz}\right.$, Cinnamyl $\left.\mathrm{H}-3,5\right), 7.11(\mathrm{~d}, 2 \mathrm{H}$, ${ }^{3} \mathrm{~J}=7.8 \mathrm{~Hz}, \mathrm{HC}=\mathrm{CHPh}$ and Cinnamyl H-4), $6.97\left(\mathrm{~d}, 2 \mathrm{H},{ }^{3} \mathrm{~J}=8.7 \mathrm{~Hz}\right.$, 4-OHPh H-3,5); ${ }^{13} \mathrm{C}$ NMR (75 MHz, DMSO- $\left.d_{6}\right) \delta$, ppm: 168.3 (1C, $\mathrm{C}=0$ ), 168.1 (1C, Oxadiazole C-3), 160.8 (1C, 4-OHPh C-4), 153.5 (1C, $\mathrm{C}=\mathrm{NH}), 149.6(1 \mathrm{C}$, Oxadiazole $\mathrm{C}-5), 141.3(1 \mathrm{C}, \mathrm{HC}=\mathrm{CHPh})$, 135.6 (1C, Cinnamyl C-1), $129.3(1 \mathrm{C}, \mathrm{HC}=\mathrm{CHPh}), 129.1(2 \mathrm{C}, 4-\mathrm{OHPh}$ C-2,6), 128.9 (2C, Cinnamyl C-3,5), 127.4 (2C, Cinnamyl C-2,6), 125.1 (1C, Cinnamyl C-4), 116.2 (2C, 4-OHPh C-3,5), 116.1 (1C, 4OHPh C-1); LCMS for $\mathrm{C}_{18} \mathrm{H}_{14} \mathrm{~N}_{4} \mathrm{O}_{3}$ calcd (found)/Error: 317.1021 $\left(317 ; 1007,\left[\left(\mathrm{M}-\mathrm{H}_{2} \mathrm{O}\right)+\mathrm{H}\right]^{ \pm}\right) / 12.7 \mathrm{ppm}$.

4.1.1.9. 3-Phenyl- $N$ '-(E-ferrocenylmethylidene)-1,2,4-oxadiazol5-ylcarbohydrazide SintMed25. Yield: 92\%; Mp 209.9-211.6 ${ }^{\circ} \mathrm{C}$ (from dioxane $\left./ \mathrm{H}_{2} \mathrm{O}\right)$; IR $\left(\mathrm{KBr}, v_{\max } \mathrm{cm}^{-1}\right)$ : $3240(\mathrm{NH}), 3064(\mathrm{Ar}$ $\mathrm{CH}), 1711(\mathrm{C}=\mathrm{O}), 1601(\mathrm{C}=\mathrm{N}$, imine), $1556(\mathrm{C}=\mathrm{N}$, heterocyclic); ${ }^{1} \mathrm{H}$ NMR (300 MHz, DMSO- $\left.d_{6}\right) \delta$, ppm: $12.5(\mathrm{~s}, 1 \mathrm{H}, \mathrm{CONH}), 8.47$ (s, $1 \mathrm{H}, \mathrm{N}=\mathrm{CH}), 8.10\left(\mathrm{~d}, 2 \mathrm{H},{ }^{3} \mathrm{~J}=7.2 \mathrm{~Hz}, \mathrm{Ar} \mathrm{H}-2,6\right), 7.65-7.63(\mathrm{~m}, 3 \mathrm{H}$, Ar H-3,4,5), 4.71 (s, 2H, C=NHFc H-2,5), 4.52 (s, 2H, C=NHFc H3,4), 4.27 (s, 5H, Fc); ${ }^{13} \mathrm{C}$ NMR (75 MHz, DMSO-d 6 ) $\delta$, ppm: 168.9 (1C, $C=0), 168.1$ (1C, Oxadiazole C-3), $153.5(1 \mathrm{C}, \mathrm{C}=\mathrm{NH}), 148.8$ (1C, Oxadiazole C-5), 132.0 (1C, Ar C-4), 129.4 (2C, Ar C-3,5), 127.2 (1C, Ar C-1), 125.5 (2C, Ar C-2,6), 77.7 (1C, C=NHFC C-1), 70.8 (2C, C=NHFC C-3,4), 69.1 (5C, Fc), 68.0 (2C, C=NHFC C-2,5); UHPLC-TOF-MS for $\mathrm{C}_{20} \mathrm{H}_{16} \mathrm{FeN}_{4} \mathrm{O}_{2}$ calcd (found)/Error: 400.0623 (401.0713, $\left.\left[\mathrm{M}+\mathrm{H}^{ \pm}\right]\right) / 3.0 \mathrm{ppm}$.

4.1.1.10. 3-(4-Tolyl)- $N^{\prime}$-(E-ferrocenylmethylidene)-1,2,4-oxadiazol-5-ylcarbohydrazide SintMed26. Yield: 91\%; Mp 220.0$222.2{ }^{\circ} \mathrm{C}$ (from dioxane $/ \mathrm{H}_{2} \mathrm{O}$ ); IR $\left(\mathrm{KBr}, v_{\max } \mathrm{cm}^{-1}\right)$ : $3182(\mathrm{NH})$, 3100, $3029(\mathrm{Ar} \mathrm{CH}), 1682(\mathrm{C}=\mathrm{O}), 1598(\mathrm{C}=\mathrm{N}$, imine $), 1547(\mathrm{C}=\mathrm{N}$, heterocyclic); ${ }^{1} \mathrm{H}$ NMR (300 MHz, DMSO- $\left.d_{6}\right) \delta$, ppm: $12.4(\mathrm{~s}, 1 \mathrm{H}$, $\mathrm{CONH}), 8.46(\mathrm{~s}, 1 \mathrm{H}, \mathrm{N}=\mathrm{CH}), 7.99\left(\mathrm{~d}, 2 \mathrm{H},{ }^{3} \mathrm{~J}=7.5 \mathrm{~Hz}, \mathrm{Ar} \mathrm{H}-2,6\right)$, $7.43\left(\mathrm{~d}, 2 \mathrm{H},{ }^{3} \mathrm{~J}=7.8 \mathrm{~Hz}, \operatorname{Ar} \mathrm{H}-3,5\right), 4.71$ (s, 2H, C=NHFC H-2,5), $4.52(\mathrm{~s}, 2 \mathrm{H}, \mathrm{C}=\mathrm{NHFC} \mathrm{H}-3,4), 4.27(\mathrm{~s}, 5 \mathrm{H}, \mathrm{Fc}), 2.41\left(\mathrm{~s}, 3 \mathrm{H}, \mathrm{CH}_{3}\right) ;{ }^{13} \mathrm{C}$ NMR (75 MHz, DMSO- $\left.d_{6}\right) \delta$, ppm: $168.7(1 \mathrm{C}, \mathrm{C}=0), 168.0$ (1C, Oxadiazole $\mathrm{C}-3), 153.5(1 \mathrm{C}, \mathrm{C}=\mathrm{NH}), 148.8$ (1C, Oxadiazole $\mathrm{C}-5)$, 142.0 (1C, Ar C-4), 129.8 (2C, Ar C-3,5), 127.1 (1C, Ar C-1), 122.6 (2C, Ar C-2,6), 77.7 (1C, C=NHFC C-1), 70.7 (2C, C=NHFC C-3,4), $69.1 \quad(5 \mathrm{C}, \mathrm{Fc}), 67.9 \quad(2 \mathrm{C}, \quad \mathrm{C}=\mathrm{NHFC} \quad \mathrm{C}-2,5), 21.0 \quad\left(1 \mathrm{C}, \mathrm{CH}_{3}\right)$; 
UHPLC-TOF-MS for $\mathrm{C}_{21} \mathrm{H}_{18} \mathrm{FeN}_{4} \mathrm{O}_{2}$ calcd (found)/Error: 414.0779 (415.0830, $\left.\left[\mathrm{M}+\mathrm{H}^{ \pm}\right]\right) / 6.5 \mathrm{ppm}$.

4.1.1.11. 3-(4-Fluorophenyl)- $N^{\prime}$-(E-ferrocenylmethylidene)1,2,4-oxadiazol-5-ylcarbohydrazide SintMed27. Yield: 94\%; Mp 209.4-211.5 ${ }^{\circ} \mathrm{C}$ (from dioxane $/ \mathrm{H}_{2} \mathrm{O}$ ); IR $\left(\mathrm{KBr}, v_{\max } \mathrm{cm}^{-1}\right)$ : 3179 $(\mathrm{NH}), 3100,3048(\mathrm{Ar} \mathrm{CH}), 1681(\mathrm{C}=\mathrm{O}), 1607(\mathrm{C}=\mathrm{N}$, imine $), 1550$ $\left(\mathrm{C}=\mathrm{N}\right.$, heterocyclic); ${ }^{1} \mathrm{H}$ NMR $\left(300 \mathrm{MHz}\right.$, DMSO- $\left.d_{6}\right) \delta$, ppm: 12.5 $(\mathrm{s}, 1 \mathrm{H}, \mathrm{CONH}), 8.46(\mathrm{~s}, 1 \mathrm{H}, \mathrm{N}=\mathrm{CH}), 8.16\left(\mathrm{dd}, 2 \mathrm{H},{ }^{4} J_{F, H}=3.0 \mathrm{~Hz}\right.$, $\left.{ }^{3} J=5.4 \mathrm{~Hz}, \operatorname{Ar} \mathrm{H}-2,6\right), 7.48\left(\mathrm{t}, 2 \mathrm{H},{ }^{3} \mathrm{~J}=8.7 \mathrm{~Hz}, \operatorname{Ar} \mathrm{H}-3,5\right), 4.71(\mathrm{~s}$, $2 \mathrm{H}, \mathrm{C}=\mathrm{NHFc} \mathrm{H}-2,5), 4.52$ (s, 2H, C=NHFc H-3,4), 4.27 (s, 5H, Fc); ${ }^{13} \mathrm{C}$ NMR (75 MHz, DMSO-d $\left.d_{6}\right) \delta$, ppm: 169.0 (1C, C=0), $167.3(1 \mathrm{C}$, Oxadiazole C-3), 164.2 (1C, d, $\left.{ }^{1} J_{F C}=249.5 \mathrm{~Hz}, \mathrm{Ar} C-4\right), 153.5$ (1C, $\mathrm{C}=\mathrm{NH}), 148.7\left(1 \mathrm{C}\right.$, Oxadiazole C-5), $129.8\left(2 \mathrm{C}, \mathrm{d},{ }^{3} \mathrm{JFC}_{\mathrm{FC}}=9.15 \mathrm{~Hz}, \mathrm{Ar}\right.$ $\mathrm{H}-2,6), 122.1$ (1C, Ar C-1), $116.6\left(2 \mathrm{C}, \mathrm{d},{ }^{2} J_{F C}=22.3 \mathrm{~Hz}, \mathrm{Ar} \mathrm{C}-3,5\right)$, 77.7 (1C, C=NHFC C-1), 70.8 (2C, C=NHFC C-3,4), 69.1 (5C, Fc), $68.0(2 \mathrm{C}, \mathrm{C}=\mathrm{NHFC} \mathrm{C}-2,5)$; UHPLC-TOF-MS for $\mathrm{C}_{20} \mathrm{H}_{15} \mathrm{FeN}_{4} \mathrm{O}_{2} \mathrm{~F}$ calcd (found): $418.0528\left(419.0622,\left[\mathrm{M}+\mathrm{H}^{ \pm}\right]\right) / 3.6 \mathrm{ppm}$.

4.1.1.12. 3-(4-Chlorophenyl)- $N^{\prime}$-(E-ferrocenylmethylidene)1,2,4-oxadiazol-5-ylcarbohydrazide SintMed28. Yield: 97\%; Mp $217.5^{\circ} \mathrm{C}$ (from dioxane $\left./ \mathrm{H}_{2} \mathrm{O}\right)$; IR $\left(\mathrm{KBr}, v_{\max } \mathrm{cm}^{-1}\right)$ : $3181(\mathrm{NH})$, 3105, $3029(\mathrm{ArCH}), 1676(\mathrm{C}=\mathrm{O}), 1600(\mathrm{C}=\mathrm{N}$, imine $), 1560(\mathrm{C}=\mathrm{N}$, heterocyclic); ${ }^{1} \mathrm{H}$ NMR (300 MHz, DMSO- $\left.d_{6}\right) \delta$, ppm: $12.5(\mathrm{~s}, 1 \mathrm{H}$, CONH), $8.46(\mathrm{~s}, 1 \mathrm{H}, \mathrm{N}=\mathrm{CH}), 8.11\left(\mathrm{~d}, 2 \mathrm{H},{ }^{3} \mathrm{~J}=8.4 \mathrm{~Hz}, \mathrm{Ar} \mathrm{H}-2,6\right)$, $7.71\left(\mathrm{~d}, 2 \mathrm{H},{ }^{3} \mathrm{~J}=8.4 \mathrm{~Hz}, \mathrm{Ar} \mathrm{H}-3,5\right), 4.71$ (s, 2H, C=NHFC H-2,5), $4.52(\mathrm{~s}, 2 \mathrm{H}, \mathrm{C}=\mathrm{NHFC} \mathrm{H}-3,4), 4.27$ (s, 5H, Fc); ${ }^{13} \mathrm{C}$ NMR $(75 \mathrm{MHz}$, DMSO- $\left.d_{6}\right) \delta$, ppm: $169.1(1 \mathrm{C}, \mathrm{C}=0), 167.3$ (1C, Oxadiazole $\left.\mathrm{C}-3\right)$, 153.6 (1C, $\mathrm{C}=\mathrm{NH}$ ), 148.7 (1C, Oxadiazole $\mathrm{C}-5$ ), 136.8 (1C, Ar C-4), 129.6 (2C, Ar C-2,6), 129.0 (1C, Ar C-1), 124.4 (2C, Ar C-3,5), 77.7 (1C, C=NHFC C-1), 70.8 (2C, C=NHFC C-3,4), 69.1 (5C, Fc), 68.1 (2C, $\mathrm{C}=\mathrm{NHFC} \mathrm{C}-2,5)$; UHPLC-TOF-MS for $\mathrm{C}_{20} \mathrm{H}_{15} \mathrm{FeN}_{4} \mathrm{ClO}_{2}$ calcd (found)/Error: $434.0233\left(435.0313,\left[\mathrm{M}+\mathrm{H}^{ \pm}\right]\right) / 0.2 \mathrm{ppm}$.

4.1.1.13. 3-(4-Bromophenyl)- $N$-(E-ferrocenylmethylidene)1,2,4-oxadiazol-5-ylcarbohydrazide SintMed29. Yield: 95\%; Mp $216.0{ }^{\circ} \mathrm{C}$ (from dioxane $\left./ \mathrm{H}_{2} \mathrm{O}\right)$; IR $\left(\mathrm{KBr}, v_{\max } \mathrm{cm}^{-1}\right)$ : $3180(\mathrm{NH})$, $3099(\mathrm{Ar} \mathrm{CH}), 1676(\mathrm{C}=\mathrm{O}), 1598(\mathrm{C}=\mathrm{N}$, imine $), 1548(\mathrm{C}=\mathrm{N}$, heterocyclic); ${ }^{1} \mathrm{H}$ NMR (300 MHz, DMSO- $\left.d_{6}\right) \delta$, ppm: 12.5 (s, $\left.1 \mathrm{H}, \mathrm{CONH}\right)$, $8.46(\mathrm{~s}, 1 \mathrm{H}, \mathrm{N}=\mathrm{CH}), 8.03\left(\mathrm{~d}, 2 \mathrm{H},{ }^{3} \mathrm{~J}=8.1 \mathrm{~Hz}, \mathrm{Ar} \mathrm{H}-2,6\right), 7.85$ (d, 2H, ${ }^{3} J=7.8 \mathrm{~Hz}$, Ar H-3,5), 4.71 (s, 2H, C=NHFC H-2,5), 4.52 (s, 2H, $\mathrm{C}=\mathrm{NHFC} \mathrm{H}-3,4), 4.26(\mathrm{~s}, 5 \mathrm{H}, \mathrm{Fc}) ;{ }^{13} \mathrm{C}$ NMR $\left(75 \mathrm{MHz}, \mathrm{DMSO}-\mathrm{d}_{6}\right) \delta$, ppm: 169.1 (1C, $C=0), 167.4$ (1C, Oxadiazole C-3), 153.6 (1C, $\mathrm{C}=\mathrm{NH}), 148.6$ (1C, Oxadiazole C-5), 132.5 (2C, Ar-C3,5), 129.1 (Ar-C2,6), 125.6 (Ar-C4), 124.7 (Ar-C1), 77.7 (Fc-C1 to imine), 70.8 (Fc-C3,4 to imine), 69.1 (Fc), 68.0 (Fc-C2,5 to imino); UHPLC-TOF-MS for $\mathrm{C}_{20} \mathrm{H}_{15} \mathrm{FeN}_{4} \mathrm{BrO}_{2}$ calcd (found)/Error: 477.9728 $\left(478.9811,\left[\mathrm{M}+\mathrm{H}^{ \pm}\right]\right) / 1.0 \mathrm{ppm}$.

4.1.1.14. 3-(4-Nitrophenyl)- $N^{\prime}$-(E-ferrocenylmethylidene)-1,2,4oxadiazol-5-ylcarbohydrazide SintMed30. Yield: 92\%; Mp 232.4$234.6{ }^{\circ} \mathrm{C}$ (from dioxane $\left./ \mathrm{H}_{2} \mathrm{O}\right)$; IR $\left(\mathrm{KBr}, v_{\max } \mathrm{cm}^{-1}\right)$ : $3181(\mathrm{NH}), 3099$ $(\mathrm{ArCH}), 1685(\mathrm{C}=\mathrm{O}), 1597(\mathrm{C}=\mathrm{N}$, imine $), 1547(\mathrm{C}=\mathrm{N}$, heterocyclic $)$; ${ }^{1} \mathrm{H}$ NMR (300 MHz, DMSO- $\left.d_{6}\right) \delta$, ppm: $12.5(\mathrm{~s}, 1 \mathrm{H}, \mathrm{CONH}), 8.49$ (d, $2 \mathrm{H},{ }^{3} \mathrm{~J}=9.0 \mathrm{~Hz}$, Ar H-3,5), $8.48(\mathrm{~s}, 1 \mathrm{H}, \mathrm{N}=\mathrm{CH}), 8.37(\mathrm{~d}, 2 \mathrm{H}$, $\left.{ }^{3} J=9.0 \mathrm{~Hz}, \operatorname{Ar~H}-2,6\right), 4.72\left(\mathrm{t}, 2 \mathrm{H},{ }^{3} \mathrm{~J}=1.5 \mathrm{~Hz}, \mathrm{C}=\mathrm{NHFC} \mathrm{H}-2,5\right), 4.53$ $\left(\mathrm{t}, 2 \mathrm{H},{ }^{3} \mathrm{~J}=1.5 \mathrm{~Hz}, \mathrm{C}=\mathrm{NHFC} \mathrm{H}-3,4\right), 4.28$ (s, 5H, Fc); ${ }^{13} \mathrm{C}$ NMR (75 MHz, DMSO- $d_{6}$ ) $\delta$, ppm: $169.4(1 \mathrm{C}, \mathrm{C}=0), 166.7$ (1C, Oxadiazole C-3), 153.7 ( $1 \mathrm{C}, \mathrm{C}=\mathrm{NH}), 149.4$ (1C, Ar C-4), 148.5 (1C, Oxadiazole C5), 131.2 (1C, Ar C-1), 128.6 (2C, Ar C-2,6), 124.5 (2C, Ar C-3,5), 77.6 (1C, C=NHFC C-1), 70.8 (2C, C=NHFC C-3,4), 69.1 (5C, Fc), 68.0 (2C, $\mathrm{C}=\mathrm{NHFC} \mathrm{C}-2,5$ ); UHPLC-TOF-MS for $\mathrm{C}_{20} \mathrm{H}_{15} \mathrm{FeN}_{5} \mathrm{O}_{4}$ calcd (found)/ Error: $445.0473\left(446.0538,\left[\mathrm{M}+\mathrm{H}^{ \pm}\right]\right) / 3.1 \mathrm{ppm}$.

4.1.1.15. 3-(4-Methoxyphenyl)- $N^{\prime}$-(E-ferrocenylmethylidene)1,2,4-oxadiazol-5-ylcarbohydrazide SintMed31. Yield: 93\%; Mp
197.7-199.0 ${ }^{\circ} \mathrm{C}$ (from dioxane/H2O); IR ( $\left.\mathrm{KBr}, v_{\max } \mathrm{cm}^{-1}\right): 3181$ $(\mathrm{NH}), 3100(\mathrm{Ar} \mathrm{CH}), 1682(\mathrm{C}=\mathrm{O}), 1611(\mathrm{C}=\mathrm{N}$, imine $), 1550(\mathrm{C}=\mathrm{N}$, heterocyclic); ${ }^{1} \mathrm{H}$ NMR (300 MHz, DMSO- $\left.d_{6}\right) \delta, \mathrm{ppm}: 12.5(\mathrm{~s}, 1 \mathrm{H}$, $\mathrm{CONH}), 8.46(\mathrm{~s}, 1 \mathrm{H}, \mathrm{N}=\mathrm{CH}), 8.05\left(\mathrm{~d}, 2 \mathrm{H},{ }^{3} \mathrm{~J}=9.0 \mathrm{~Hz}, \mathrm{Ar} \mathrm{H}-2,6\right)$, $7.17\left(\mathrm{~d}, 2 \mathrm{H},{ }^{3} \mathrm{~J}=8.7 \mathrm{~Hz}, \mathrm{Ar} \mathrm{H}-3,5\right), 4.71\left(\mathrm{t}, 2 \mathrm{H},{ }^{3} \mathrm{~J}=1.5 \mathrm{~Hz}, \mathrm{C}=\mathrm{NHFC}\right.$ $\mathrm{H}-2,5), 4.53\left(\mathrm{t}, 2 \mathrm{H},{ }^{3} \mathrm{~J}=1.5 \mathrm{~Hz}, \mathrm{C}=\mathrm{NHFC} \mathrm{H}-3,4\right), 4.27$ (s, 5H, Fc), $3.86\left(\mathrm{~s}, 3 \mathrm{H}, \mathrm{OCH}_{3}\right) ;{ }^{13} \mathrm{C}$ NMR $\left(75 \mathrm{MHz}, \mathrm{DMSO}-d_{6}\right) \delta$, ppm: 168.7 (1C, $\mathrm{C}=0$ ), 167.8 (1C, Oxadiazole C-3), 162.1 (1C, Ar C-4), 153.5 (1C, $\mathrm{C}=\mathrm{NH}), 148.8$ (1C, Oxadiazole C5), 128.9 (2C, Ar C-2,6), 117.7 (1C, Ar C-1), 114.8 (2C, Ar C-3,5), 77.8 (1C, C=NHFC C-1), 70.8 (2C, C=NHFc C-3,4), 69.1 (5C, Fc), 68.0 (2C, C=NHFC C-2,5), 55.5 (1C, $\mathrm{OCH}_{3}$ ); UHPLC-TOF-MS for $\mathrm{C}_{21} \mathrm{H}_{18} \mathrm{FeN}_{4} \mathrm{O}_{3}$ calcd (found)/ Error: $430.0728\left(431.0822,\left[\mathrm{M}+\mathrm{H}^{ \pm}\right]\right) / 3.5 \mathrm{ppm}$.

4.1.1.16. 3-(4-Hydroxyphenyl)- $N$ '-(E-ferrocenylmethylidene)1,2,4-oxadiazol-5-ylcarbohydrazide SintMed32. Yield: $83 \%$; Mp 221.3-223.0 ${ }^{\circ} \mathrm{C}$ (from dioxane $\left./ \mathrm{H}_{2} \mathrm{O}\right)$; IR $\left(\mathrm{KBr}, v_{\max } \mathrm{cm}^{-1}\right)$ : 3313 (br OH), $3180(\mathrm{NH}), 3100(\mathrm{Ar} \mathrm{CH}), 1702(\mathrm{C}=\mathrm{O}), 1611(\mathrm{C}=\mathrm{N}$, imine), $1564\left(\mathrm{C}=\mathrm{N}\right.$, heterocyclic); ${ }^{1} \mathrm{H}$ NMR $\left(300 \mathrm{MHz}\right.$, DMSO- $\left.d_{6}\right) \delta$, ppm: $12.4(\mathrm{~s}, 1 \mathrm{H}, \mathrm{CONH}), 10.2(\mathrm{~s}, 1 \mathrm{H}, \mathrm{OH}), 8.44(\mathrm{~s}, 1 \mathrm{H}, \mathrm{N}=\mathrm{CH}), 7.93(\mathrm{~d}$, $\left.2 \mathrm{H},{ }^{3} \mathrm{~J}=6.4 \mathrm{~Hz}, \mathrm{Ar} \mathrm{H}-2,6\right), 6.97\left(\mathrm{~d}, 2 \mathrm{H},{ }^{3} \mathrm{~J}=6.0 \mathrm{~Hz}, \mathrm{Ar} \mathrm{H}-3,5\right), 4.70$ (s, $2 \mathrm{H}, \mathrm{C}=\mathrm{NHFC} \mathrm{H}-2,5), 4.51(\mathrm{~s}, 2 \mathrm{H}, \mathrm{C}=\mathrm{NHFC} \mathrm{H}-3,4), 4.27(\mathrm{~s}, 5 \mathrm{H}$, Fc); ${ }^{13} \mathrm{C}$ NMR (75 MHz, DMSO-d $\left.d_{6}\right) \delta$, ppm: $168.4(1 \mathrm{C}, \mathrm{C}=0), 167.9$ (1C, Oxadiazole C-3), 160.7 (1C, Ar C-4), 153.4 (1C, C=NH), 148.9 (1C, Oxadiazole C-5), 129.0 (2C, Ar C-2,6), 116.1 (1C, Ar C-1), 116.1 (2C, Ar C-3,5), 77.8 (1C, C=NHFC C-1), 70.8 (2C, C=NHFC C-3,4), 69.1 (5C, Fc), 68.0 (2C, C=NHFC C-2,5); UHPLC-TOF-MS for $\mathrm{C}_{20} \mathrm{H}_{16} \mathrm{FeN}_{4} \mathrm{O}_{3}$ calcd (found)/Error: 416.0572 (417.0664, $\left.\left[\mathrm{M}+\mathrm{H}^{ \pm}\right]\right) / 3.4 \mathrm{ppm}$.

\subsection{Pharmacological evaluation}

\subsubsection{Cytotoxicity assay}

HepG2 cells in RPMI-1640 medium without phenol red (Sigma Chemical Co., MO, USA) plus 10\% fetal bovine serum (FBS; Cultilab, Campinas, SP, Brazil) and $50 \mu \mathrm{g} \mathrm{mL}^{-1}$ of gentamycin (Novafarma, Anápolis, GO, Brazil) were seeded in 96-well plates (104 cells/well in $100 \mu \mathrm{L}$ of medium). After $24 \mathrm{~h}$, the compounds, diluted in RPMI1640 medium without phenol red, were added $(100 \mu \mathrm{L})$ in five concentrations, in triplicate, and the plates incubated for $72 \mathrm{~h}$ at $37^{\circ} \mathrm{C}$ and $5 \% \mathrm{CO}_{2}$. After this period, $20 \%$ of AlamarBlue (Invitrogen, Carlsbad, CA) was added to each well and the plate incubated for $24 \mathrm{~h}$. The absorbance at 570 and $600 \mathrm{~nm}$ was measured according to manufacturer's instructions. Gentian Violet (Synth, São Paulo, Brazil) was used as a cytotoxicity control. Controls with untreated cells were read in parallel and triplicates are read in the same plate. The $\mathrm{CC}_{50}$ values were calculated using a non-linear regression curve fit in the Graph Pad Prism version 5.03 (Graph Pad Software, San Diego, CA).

\subsubsection{Anti-P. falciparum activity}

W2 strain $P$. falciparum was maintained in continuous culture of human erythrocytes (blood group $\mathrm{O}^{+}$) using the RPMI 1640 medium supplemented with $10 \%$ of human plasma. Parasites grown at $1 \%$ parasitemia and $2.5 \%$ hematocrit were distributed into 96 wells culture plate and incubated with the compounds (previously diluted with $4 \%$ DMSO and culture medium). After $24 \mathrm{~h}$ of incubation, $\left[{ }^{3} \mathrm{H}\right]$-hypoxanthine was added, the plate incubated again for $24 \mathrm{~h}$, cooled for $24 \mathrm{~h}$ and then parasites were harvested using a cell harvester to quantify the $\left[{ }^{3} \mathrm{H}\right]$-hypoxanthine incorporation in a $\beta$-radiation counter. Inhibition of parasite growth was evaluated by comparison with $\left[{ }^{3} \mathrm{H}\right]$-hypoxanthine uptake in treated versus untreated parasite. Each compound was initially tested at concentration of $10 \mu \mathrm{g} / \mathrm{mL}$ in triplicate and the $\mathrm{IC}_{50}$ values were calculated in triplicate concentration using at least five concentrations. Mefloquine (Mfq) was used as a standard drug. 


\subsubsection{Hemolysis assay}

The hemolytic activity of the compounds was assayed in fresh human erythrocytes (type $\left.\mathrm{O}^{+}\right){ }^{23}$ Cells were washed three times with phosphate buffered saline, and $100 \mu \mathrm{L}$ of this suspension ( $1 \%$ hematocrit) was distributed into each well to a 96 -well plate. After, $100 \mu \mathrm{L}$ of each compound ( $N$-acylhydrazone), previously dissolved in phosphate buffered saline, were added in triplicate to the plate and incubated for $1 \mathrm{~h}$. Saponin (Sigma-Aldrich, USA) was used as a hemolytic drug at $1 \% \mathrm{v} / \mathrm{v}$. After incubation, samples were centrifuged (1500 rpm for $10 \mathrm{~min}$ ) and $100 \mu \mathrm{L}$ of each supernatant was transferred to another microtiter plate. Released haemoglobin was monitored by measuring the absorbance at $540 \mathrm{~nm}$ in a spectrophotometer. The percentage of hemolysis was calculated as previously described.

\subsubsection{Inhibition of $\beta$-hematin formation}

$50 \mu \mathrm{L}$ of a freshly prepared solution of haemin $(0.5 \mathrm{mg} / \mathrm{mL})$ dissolved in $0.2 \mathrm{M} \mathrm{NaOH}$ was mixed to a $75 \mu \mathrm{L}$ of $3 \mathrm{M}$ sodium acetate, $25 \mu \mathrm{L}$ of $17.4 \mathrm{M}$ acetic acid and $50 \mu \mathrm{L}$ of the tested compounds $(N-$ acylhydrazones). All $\mathrm{N}$-acylhydrazones were tested at $2.5 \mathrm{mM}$. After $24 \mathrm{~h}$ of incubation at $37^{\circ} \mathrm{C}$, the resulting solution was spun down for $15 \mathrm{~min}$ at $3500 \mathrm{rpm}$, the supernatant was discarded off and the pellet washed with $200 \mu \mathrm{L}$ of DMSO. This step was repeated once and after a final wash with water, the pellet was dissolved in $0.1 \mathrm{M} \mathrm{NaOH}(150 \mu \mathrm{L})$. Chloroquine (CQ) was included in each experiment as positive control. The absorption at $405 \mathrm{~nm}$ was read using a spectrophotometer. Results are expressed as percentage of inhibition of hematin formation in comparison to the negative control (without compound). Experiments were carried out at least twice using compound concentrations in triplicate.

\subsubsection{Antimalarial tests against Plasmodium berghei in mice}

Adult Swiss mice (4-6 weeks) were inoculated by intraperitoneal route with $10^{6}$ infected red blood cells with NK65 strain $P$. berghei. The infected mice were randomly divided into groups of $n=5$ and subsequently treated with compounds SintMed2, SintMed5 or SintMed6 diluted in DMSO 20\% given once a day for four consecutive days by oral gavage or intraperitoneal. Two control groups were used in parallel, one treated with Chloroquine $(50 \mathrm{mg} / \mathrm{kg}$ ), standard drug, and one with the vehicle (DMSO $20 \%$ in saline solution). Blood smears from mice tails were prepared on days $4,5,6,7$ and 8 post-infection and then methanol-fixed, stained with fast panoptic (Laborclin, Pinhais, Brazil) and examined by optical microscopy. The parasitemia was evaluated and the percent inhibition of parasite growth calculated in relation to the untreated control group (considered 100\% growth) using the following equation: $[(C-T) / C] \times 100$; where $C$ is the parasitemia where $C$ is the parasitemia in the control group and $T$ is the parasitemia in the treated group.

\section{Acknowledgments}

This work received support from FAPESB. The authors are grateful to Mrs. Eliete de Fátima V. B. N. da Silva, Mrs. Abene Silva Ribeiro and the Analytical Centre of Fundamental Chemistry Department, Universidade Federal de Pernambuco, for the NMR experiments.

\section{A. Supplementary data}

Supplementary data associated with this article can be found, in the online version, at http://dx.doi.org/10.1016/j.bmc.2016.09.013. These data include MOL files and InChiKeys of the most important compounds described in this article.

\section{References and notes}

1. Cotter, C.; Sturrock, H. J.; Hsiang, M. S.; Liu, J.; Phillips, A. A.; Hwang, J.; Gueye, C. S.; Fullman, N.; Gosling, R. D.; Feachem, R. G. Lancet 2013, 382, 900.

2. Mishra, N.; Prajapati, S. K.; Kaitholia, K.; Bharti, R. S.; Srivastava, B.; Phookan, S.; Anvikar, A. R.; Dev, V.; Sonal, G. S.; Dhariwal, A. C.; White, N. J.; Valecha, N. Antimicrob. Agents Chemother. 2015, 59, 2548.

3. Price, R. N.; von Seidlein, L.; Valecha, N.; Nosten, F.; Baird, J. K.; White, N. J. Lancet Infect. Dis. 2014, 14, 982.

4. Jacobs, R. T.; Plattner, J. J.; Keenan, M. Curr. Opin. Infect. Dis. 2011, 24, 586.

5. Da Cruz, F. P.; Martin, C.; Buchholz, K.; Lafuente-Monasterio, M. J.; Rodrigues, T.; Sönnichsen, B.; Moreira, R.; Gamo, F. J.; Marti, M.; Mota, M. M.; Hannus, M.; Prudêncio, M. J. Infect. Dis. 2012, 205, 1278.

6. Wang, X.; Dong, Y.; Wittlin, S.; Charman, S. A.; Chiu, F. C.; Chollet, J.; Katneni, K.; Mannila, J.; Morizzi, J.; Ryan, E.; Scheurer, C.; Steuten, J.; Santo-Tomas, J.; Snyder, C.; Vennerstrom, J. L. J. Med. Chem. 2013, 56, 2547.

7. White, N. J.; Pukrittayakamee, S.; Phyo, A. P.; Rueangweerayut, R.; Nosten, F.; Jittamala, P.; Jeeyapant, A.; Jain, J. P.; Lefèvre, G.; Li, R.; Magnusson, B.; Diagana, T. T.; Leong, F. J. N. Engl. J. Med. 2014, 371, 403.

8. Wein, S.; Tran-Van-Ba, C.; Maynadier, M.; Bordat, Y.; Perez, J.; Peyrottes, S.; Fraisse, L. Vial, H. J. Antimicrob. Agents Chemother. 2014, 58, 5519.

9. Stokes, N. R.; Baker, N.; Bennett, J. M.; Chauhan, P. K.; Collins, I.; Davies, D. T.; Gavade, M.; Kumar, D.; Lancett, P.; Macdonald, R.; Macleod, L.; Mahajan, A.; Mitchell, J. P.; Nayal, N.; Nayal, Y. N.; Pitt, G. R.; Singh, M.; Yadav, A.; Srivastava, A.; Czaplewski, L. G.; Haydon, D. J. Bioorg. Med. Chem. Lett. 2014, 24, 353.

10. Rackham, M. D.; Brannigan, J. A.; Rangachari, K.; Meister, S.; Wilkinson, A. J.; Holder, A. A.; Leatherbarrow, R. J.; Tate, E. W. J. Med. Chem. 2014, 57, 2773.

11. Soeiro, M. N.; de Souza, E. M. da Silva, C. F ; Batista, D. G · Batista, M. M.; Pavão, B. P.; Araújo, J. S.; Aiub, C. A.; da Silva, P. B.; Lionel, J.; Britto, C.; Kim, K.; Sulikowski, G.; Hargrove, T. Y.; Waterman, M. R.; Lepesheva, G. I. Antimicrob. Agents Chemother. 2013, 57, 4151.

12. Ross, F.; Hernández, P.; Porcal, W.; López, G. V.; Cerecetto, H.; González, M.; Basika, T.; Carmona, C.; Fló, M.; Maggioli, G.; Bonilla, M.; Gladyshev, V. N.; Boiani, M.; Salinas, G. PLoS One 2012, 7, e35033.

13. Lepesheva, G. I.; Hargrove, T. Y.; Rachakonda, G.; Wawrzak, Z.; Pomel, S. Cojean, S.; Nde, P. N.; Nes, W. D.; Locuson, C. W.; Calcutt, M. W.; Waterman, M. R.; Daniels, J. S.; Loiseau, P. M.; Villalta, F. J. Infect. Dis. 2015, 212, 1439.

14. dos Santos Filho, J. M.; Leite, A. C.; de Oliveira, B. G.; Moreira, D. R.; Lima, M. S.; Soares, M. B.; Leite, L. F. C. Bioorg. Med. Chem. 2009, 17, 6682.

15. dos Santos Filho, J. M.; Moreira, D. R.; de Simone, C. A.; Ferreira, R. S.; McKerrow, J. H.; Meira, C. S.; Guimarães, E. T.; Soares, M. B. Bioorg. Med. Chem. 2012, 20, 6423.

16. Mombelli, P.; Witschel, M. C.; van Zijl, A. W.; Geist, J. G.; Rottmann, M.; Freymond, C.; Röhl, F.; Kaiser, M.; Illarionova, V.; Fischer, M.; Siepe, I.; Schweizer, W. B.; Brun, R.; Diederich, F. ChemMedChem 2012, 7, 151.

17. Inam, A.; Siddiqui, S. M.; Macedo, T. S.; Moreira, D. R.; Leite, A. C.; Soares, M. B.; Azam, A. Eur. J. Med. Chem. 2014, 75, 67.

18. Kumar, R.; Sharma, P. K.; Mishra, P. S. Int. J. PharmTech Res. 2012, 4, 266. http:// dx.doi.org/10.1002/chin.201228263.

19. (a) Gomes, A.; Pérez, B.; Albuquerque, I.; Machado, M.; Prudêncio, M.; Nogueira, F.; Teixeira, C.; Gomes, P. ChemMedChem 2014, 9, 305; (b) Pérez, B.; Teixeira, C.; Gomes, A. S.; Albuquerque, I. S.; Gut, J.; Rosenthal, P. J.; Prudêncio, M.: Gomes, P. Bioorg. Med. Chem. Lett. 2013, 23, 610.

20. (a) Dubar, F.; Slomianny, C.; Khalife, J.; Dive, D.; Kalamou, H.; Guérardel, Y.; Grellier, P.; Biot, C. Angew. Chem., Int. Ed. 2013, 52, 7690; (b) Biot, C.; Glorian, G.; Maciejewski, L. A.; Brocard, J. S.; Domarle, O.; Blampain, G.; Millet, P.; Georges, A. J.; Abessolo, H.; Dive, D.; Lebibi, J. J. Med. Chem. 1997, 40, 3715.

21. dos Santos Filho, J. M. Eur. J. Org. Chem. 2014, 29, 6411.

22. Spencer, J.; Mendham, A. P.; Kotha, A. K.; Richardson, S. C.; Hillard, E. A.; Jaouen, G.; Male, L.; Hursthouse, M. B. Dalton Trans. 2009, 6, 918.

23. Silva, B. V.; Ribeiro, N. M.; Pinto, A. C.; Vargas, M. D.; Dias, L. C. J. Braz. Chem. Soc. 2008, 19, 1244 